\title{
Explaining global surface aerosol number concentrations in terms of primary emissions and particle formation
}

\author{
D. V. Spracklen ${ }^{1}$, K. S. Carslaw ${ }^{1}$, J. Merikanto ${ }^{1}$, G. W. Mann ${ }^{1}$, C. L. Reddington ${ }^{1}$, S. Pickering ${ }^{1}$, J. A. Ogren ${ }^{2}$, \\ E. Andrews ${ }^{2}$, U. Baltensperger ${ }^{3}$, E. Weingartner ${ }^{3}$, M. Boy ${ }^{4}$, M. Kulmala ${ }^{4}$, L. Laakso ${ }^{4}$, H. Lihavainen ${ }^{5}$, N. Kivekäs ${ }^{5}$, \\ M. Komppula ${ }^{5,20}$, N. Mihalopoulos ${ }^{6}$, G. Kouvarakis ${ }^{6}$, S. G. Jennings ${ }^{7}$, C. O'Dowd ${ }^{7}$, W. Birmili ${ }^{8}$, A. Wiedensohler ${ }^{8}$, \\ R. Weller ${ }^{9}$, J. Gras ${ }^{10}$, P. Laj ${ }^{11}$, K. Sellegri ${ }^{12}$, B. Bonn ${ }^{13}$, R. Krejci ${ }^{14}$, A. Laaksonen ${ }^{5,15}$, A. Hamed ${ }^{15}$, A. Minikin ${ }^{16}$, \\ R. M. Harrison ${ }^{17}$, R. Talbot ${ }^{18}$, and J. Sun ${ }^{19}$ \\ ${ }^{1}$ Institute for Climate and Atmospheric Science, School of Earth and Environment, University of Leeds, LS2 9JT, UK \\ ${ }^{2}$ NOAA/ESRL Global Monitoring Division, 325 Broadway R/GMD1, Boulder, Co 80305, USA \\ ${ }^{3}$ Paul Scherrer Institut, Laboratory of Atmospheric Chemistry, 5232 Villigen, Switzerland \\ ${ }^{4}$ Department of Physics, University of Helsinki, 00014 Helsinki, Finland \\ ${ }^{5}$ Climate Change, Finnish Meteorological Institute, P.O. Box 503, 00101, Helsinki, Finland \\ ${ }^{6}$ Department of Chemistry, University of Crete, University campus, P.O. Box 2208, 71003, Voutes, Heraklion, Crete, Greece \\ ${ }^{7}$ Department of Physics, National University of Ireland, Galway, Ireland \\ ${ }^{8}$ Leibniz Institute for Tropospheric Research, Permoserstrasse 15, 04318 Leipzig, Germany \\ ${ }^{9}$ Alfred Wegener Institute, Am Handelshafen 12, 27570 Bremerhaven, Germany \\ ${ }^{10}$ CSIRO Marine and Atmospheric Research, Ctr Australian Weather and Climate Res, Aspendale, Victoria, Australia \\ ${ }^{11}$ Laboratoire de Glaciologie et Géophysique de l'Environnement CNRS/Université Grenoble 1, Grenoble, France \\ ${ }^{12}$ Laboratoire de Météorologie Physique, Université Clermont-Ferrand/ CNRS, Clermont-Ferrand, France \\ ${ }^{13}$ Institute for Atmospheric and Environmental Sciences, J. W. Goethe University, Frankfurt/Main, Germany \\ ${ }^{14}$ Department of Applied Environmental Science (ITM), Stockholm University, 10691 Stockholm, Sweeden \\ ${ }^{15}$ Department of Physics and Mathematics, University of Eastern Finland, (Kuopio campus), P.O. Box 70211 Kuopio, Finland \\ ${ }^{16}$ Deutsches Zentrum für Luft- und Raumfahrt (DLR), Institut fr Physik der Atmosphäre, Oberpfaffenhofen, Germany \\ ${ }^{17}$ National Centre for Atmospheric Science, School of Geography, Earth and Environmental Sciences, University of \\ Birmingham, Edgbaston, Birmingham B15 2TT, UK \\ ${ }^{18}$ Climate Change Research Center, University of New Hampshire, Durham, NH 03824 USA \\ ${ }^{19}$ Key Laboratory for Atmospheric Chemistry of CMA, Center for Atmosphere Watch and Services, Chinese Academy of \\ Meteorological Sciences, CMA, Beijing 100081, China \\ ${ }^{20}$ Kuopio Unit, Finnish Meteorological Institute, Kuopio, Finland
}

Received: 10 November 2009 - Published in Atmos. Chem. Phys. Discuss.: 10 December 2009

Revised: 3 May 2010 - Accepted: 17 May 2010 - Published: 26 May 2010

\begin{abstract}
We synthesised observations of total particle number $(\mathrm{CN})$ concentration from 36 sites around the world. We found that annual mean $\mathrm{CN}$ concentrations are typically 300 $2000 \mathrm{~cm}^{-3}$ in the marine boundary layer and free troposphere (FT) and 1000-10 $000 \mathrm{~cm}^{-3}$ in the continental boundary layer (BL). Many sites exhibit pronounced seasonality with summer time concentrations a factor of 2-10 greater than wintertime concentrations. We used these $\mathrm{CN}$ obser-
\end{abstract}

Correspondence to: D. V. Spracklen (dominick@env.leeds.ac.uk) vations to evaluate primary and secondary sources of particle number in a global aerosol microphysics model. We found that emissions of primary particles can reasonably reproduce the spatial pattern of observed $\mathrm{CN}$ concentration $\left(R^{2}=0.46\right)$ but fail to explain the observed seasonal cycle $\left(R^{2}=0.1\right)$. The modeled $\mathrm{CN}$ concentration in the FT was biased low (normalised mean bias, $\mathrm{NMB}=-88 \%$ ) unless a secondary source of particles was included, for example from binary homogeneous nucleation of sulfuric acid and water $(\mathrm{NMB}=-25 \%)$. Simulated CN concentrations in the continental BL were also biased low $(\mathrm{NMB}=-74 \%)$ unless the number emission of anthropogenic primary particles was increased or a

Published by Copernicus Publications on behalf of the European Geosciences Union. 
mechanism that results in particle formation in the BL was included. We ran a number of simulations where we included an empirical BL nucleation mechanism either using the activation-type mechanism (nucleation rate, $J$, proportional to gas-phase sulfuric acid concentration to the power one) or kinetic-type mechanism ( $J$ proportional to sulfuric acid to the power two) with a range of nucleation coefficients. We found that the seasonal $\mathrm{CN}$ cycle observed at continental BL sites was better simulated by BL particle formation $\left(R^{2}=0.3\right)$ than by increasing the number emission from primary anthropogenic sources $\left(R^{2}=0.18\right)$. The nucleation constants that resulted in best overall match between model and observed $\mathrm{CN}$ concentrations were consistent with values derived in previous studies from detailed case studies at individual sites. In our model, kinetic and activation-type nucleation parameterizations gave similar agreement with observed monthly mean $\mathrm{CN}$ concentrations.

\section{Introduction}

There are two sources of particles in the atmosphere. Primary particles are emitted directly to the atmosphere and secondary particles are formed from gas-to-particle conversion. The relative contribution of these two sources to global aerosol is poorly understood, but it is important to quantify if we are to understand long-term aerosol trends and the impact of aerosol on climate. Here we use observations of total particle number concentration at sites around the world together with a global aerosol model to understand the sources of particle number.

Primary particles are emitted directly to the atmosphere, for example from biomass burning, combustion of fossil fuels and uplift of sea-spray and dust from the Earth's surface. While the emission strength of primary particles has been relatively well studied less is known about the size distribution of these emissions. A small uncertainty in the size distribution of primary particles (for a given mass) leads to a large uncertainty in the number emission of particles and results in substantial uncertainty in the atmospheric particle number concentration (Spracklen et al., 2005b).

Secondary particles formed from particle formation are observed at many surface locations around the world and also within the free and upper troposphere (Kulmala et al., 2004). Particle formation events are associated with a rapid increase in the number concentration of ultrafine particles followed by particle growth. Such events have been observed at sites ranging from Antarctica (Koponen et al., 2003), Arctic (Vehkamäki et al., 2004), boreal forest (Mäkelä et al., 1997; Kulmala et al., 1998b; Dal Maso et al., 2005), suburban and urban regions (Birmili and Wiedensohler, 2000; Gaydos et al., 2005) and coastal environments (O’Dowd et al., 1999). Several observations using multiple measurement stations have shown that formation events can occur more or less uni- formly in air masses extending over hundreds of kilometres (Kulmala et al., 1998b, 2001; Vana et al., 2004; Komppula et al., 2006). Large concentrations of ultrafine $(<20 \mathrm{~nm})$ particles have also been observed in the free and upper troposphere (e.g., Clarke et al., 1998, 1999; Weingartner et al., 1999; Minikin et al., 2003) and frequent new particle formation has now also been recorded at high altitude surface sites (Venzac et al., 2008). The importance of secondary particle formation on a global scale is uncertain, though it may make a significant contribution to both global condensation nuclei (CN) (Spracklen et al., 2006) and cloud condensation nuclei (CCN) concentrations (Spracklen et al., 2008; Kuang et al., 2009; Makkonen et al., 2009; Pierce and Adams, 2009; Wang and Penner, 2009).

Despite such frequent occurence in the atmosphere, and potential importance to global aerosol, the underlying mechanism of new particle formation is not known. Several mechanisms have been proposed including binary homogeneous nucleation (BHN) of $\mathrm{H}_{2} \mathrm{SO}_{4}-\mathrm{H}_{2} \mathrm{O}$ (Jaecker-Voirol and Mirabel, 1988; Kulmala et al., 1998a; Vehkamäki et al., 2002), ternary nucleation (TN) of $\mathrm{H}_{2} \mathrm{SO}_{4}-\mathrm{H}_{2} \mathrm{O}-\mathrm{NH}_{3}$ (Napari et al., 2002) and ion-induced nucleation (Modgil et al., 2005). $\mathrm{BHN}$ is strongly temperature dependent and only produces new particles in the cold free and upper troposphere (Weber et al., 1999; Adams and Seinfeld, 2002; Spracklen et al., 2005a; Lucas and Akimoto, 2006). Revised parameterizations of ternary nucleation (Yu, 2006; Anttila et al., 2005; Merikanto et al., 2007) also suggest that this mechanism is not a significant source of particles in the lower troposphere (Elleman and Covert, 2009). Neither of these mechanisms is therefore likely to explain particle formation observed in the boundary layer (BL). Ion-induced nucleation potentially contributes to both free troposphere (FT) and BL particle formation (Kazil et al., 2006; Yu et al., 2008). However, other studies suggest that ion-induced nucleation plays a minimal role (Kulmala et al., 2007; Boy et al., 2008; Mirme et al., 2010).

While our mechanistic understanding of nucleation remains so uncertain, an alternative approach has been used to explain observed particle formation and to estimate the impact of nucleation on global aerosol properties. Observations of surface particle formation events have been analysed to develop empirical particle formation mechanisms. The formation rate of molecular clusters ( $1 \mathrm{~nm}$ to $1.5 \mathrm{~nm}$ in diameter) is found to be proportional to the gas-phase sulfuric acid concentration to the power 1 to 2 (Weber et al., 1996; Kulmala et al., 2006; Sihto et al., 2006; Riipinen et al., 2007; Kuang et al., 2008). The power one dependence of the cluster formation rate on sulfuric acid has been described in terms of an activation mechanism (Kulmala et al., 2006) where sulfuric acid particles are stabilized by a secondary species such as organics. A power two dependence has been explained by proposing a kinetic nucleation mechanism (McMurry and Friedlander, 1979). 
The development of global aerosol microphysics models in recent years means that we can now prognose $\mathrm{CN}$ and $\mathrm{CCN}$ concentrations for the first time (e.g., Adams and Seinfeld, 2002, 2003; Easter et al., 2004; Pierce and Adams, 2006; Pierce et al., 2007; Spracklen et al., 2005a,b; Stier et al., 2005). Such models are being used to understand the processes controlling global aerosol and so there is an urgent need to evaluate these new models against observations. The significant uncertainties associated both with the treatment of primary emissions and particle formation mean that model skill may be lacking. The size of primary particles emitted in global models must take into account the size distribution of the primary particles at the point of emission as well as the ageing that occurs at sub-model grid scales (Pierce et al., 2009). Because the mechanisms of atmospheric new particle formation are unknown there are also significant uncertainties in the global secondary particle formation rate (Spracklen et al., 2008).

Previous work suggests that remote marine boundary layer (MBL) particle number size distributions can largely be explained by a combination of entrainment of particles from the FT (produced by particle formation in the upper troposphere(UT)) and primary sea-salt emissions, although there are significant regional discrepancies between model and observations (Easter et al., 2004; Spracklen et al., 2005a, 2007; Pierce and Adams, 2006; Trivitayanurak et al., 2008). Vertical profiles of $\mathrm{CN}$ over the remote MBL have also be explained by BHN (Spracklen et al., 2005a).

Simulated CN concentrations in the continental BL are greatly enhanced by primary sulfate (Adams and Seinfeld, 2002, 2003; Spracklen et al., 2005b; Wang et al., 2009), carbonaceous aerosol (Pierce et al., 2007) and BL particle formation (Spracklen et al., 2006, 2008; Makkonen et al., 2009; Chang et al., 2009). While Pierce and Adams (2009) show that observed $\mathrm{CN}$ at continental BL sites can be largely explained by primary emissions alone, other studies suggest a large contribution from particle formation (Spracklen et al., 2006, 2008; Makkonen et al., 2009).

In this study, we use observations of total particle number concentration together with a global aerosol model to better understand the contribution of particle formation and primary emissions to global aerosol number. We compile measurements of the total particle number concentration, reported for particle sizes larger than a few nanometers (typically $3-10 \mathrm{~nm}$ in diameter), from 36 surface sites around the world. Although such small particles are not directly relevant to climate, our dataset is the largest available for evaluating aerosol microphysics models and to understand the sources of global aerosol number. Furthermore, it is thought that subsequent growth of these particles to larger sizes may contribute significantly to both local and global concentrations of CCN (e.g., Laaksonen et al., 2005; Spracklen et al., 2008; Kuang et al., 2009; Wiedensohler et al., 2009) making them indirectly important to climate.

\section{Model description}

\subsection{General}

We use the GLOMAP aerosol microphysics model (Spracklen et al., 2005a,b), which is an extension of the TOMCAT 3-D global chemical transport model (Chipperfield, 2006) to simulate sulfate (SU), sea salt (SS), elemental carbon (EC) and organic carbon (OC) for the year 2000. Large-scale transport and meteorology is specified from 6h European Centre for Medium-Range Weather Forecasts (ECMWF) analyses. We use a horizontal resolution of $\sim 2.8^{\circ}$ by $\sim 2.8^{\circ}$ and 31 vertical levels between the surface and $10 \mathrm{hPa}$.

GLOMAP treats the particle size distribution using either a two-moment modal (Manktelow et al., 2007) or a twomoment sectional (bin) (Spracklen et al., 2005a) scheme. Here we use the sectional scheme and treat two externally mixed distributions, each described with 20 sections spanning $3 \mathrm{~nm}$ to $10 \mu \mathrm{m}$ dry diameter. One distribution, representing freshly emitted primary carbonaceous aerosol, contains OC and EC, is treated as non-hydrophilic and is not wet scavenged. The other distribution contains SU, SS, EC and OC, is hydrophilic and is wet scavenged. Total simulated particle number is the sum of particles in these two distributions. The microphysical processes in the model include nucleation, coagulation, condensation of gas-phase species, in-cloud and below-cloud aerosol scavenging and deposition, dry deposition and cloud processing.

Non-hydrophilic particles age to become hydrophilic through condensation of soluble gas-phase species (includes sulfuric acid and secondary organic aerosol (SOA) precursors) and coagulation with hydrophilic particles. In all the experiments described here we assumed that a single monolayer coating of soluble material is sufficient to age nonhydrophilic to hydrophilic particles. We test the sensitivity to this assumption by running an additional simulation where we increased the amount of soluble material required to age non-hydrophilic particles by a factor of 5 . This reduced the rate of ageing and increased the global surface mean concentration of non-hydrophilic particles by a factor of 2 . The resulting increase in pre-existing aerosol surface area suppressed nucleation and reduced hydrophilic particle number by $10 \%$ (in a scenario where the secondary source of particles is from binary homogeneous nucleation). Total CN concentration (hydrophilic and non-hyrophilic particles) is relatively insensitive to this change decreasing by only $4 \%$ globally.

Concentrations of $\mathrm{OH}, \mathrm{O}_{3}$ and $\mathrm{NO}_{3}$ and $\mathrm{HO}_{2}$ are specified using 6-h monthly mean 3-D concentrations from a TOMCAT simulation with detailed tropospheric chemistry (Arnold et al., 2005). Concentrations of $\mathrm{H}_{2} \mathrm{O}_{2}$ are calculated as described in Spracklen et al. (2005a).

Oceanic DMS emissions are calculated using the ocean surface DMS concentration database of Kettle and An- 
dreae (2000) and the sea-to-air transfer velocity according to Nightingale et al. (2000). Emissions of biogenic terpenes are from the GEIA inventory (Benkovitz et al., 1996) and are based on Guenther et al. (1995). Emissions of $\mathrm{SO}_{2}$ and carbonaceous aerosol from wildfires, biofuel, fossil fuel and volcanoes are based on the AEROCOM ${ }^{1}$ emission inventories for the year 2000 (Dentener et al., 2006).

SOA from biogenic terpenes is included assuming the reactivity of alpha-pinene including reactions with $\mathrm{OH}, \mathrm{O}_{3}$ and $\mathrm{NO}_{3}$ (Spracklen et al., 2006). We assume all three reactions have a constant yield of $13 \%$ to a first-stage oxidation product that condenses with zero vapour pressure onto existing aerosol (Spracklen et al., 2006). We assume that SOA is hydrophilic.

\subsection{Primary emissions and particle formation}

We test the sensitivity of the model to the emission of primary particles and the nucleation rate through a series of experiments detailed below and in Table 1 .

1. Experiment PRI includes anthropogenic and natural primary particulate emissions but no secondary particle formation. Primary sea-spray emissions are based on Gong et al. (2003). We assume that a fraction of sulfur dioxide emissions are emitted as primary sulfate either because these particles are directly emitted to the atmosphere or because they are formed through gasto-particle conversion at spatial scales smaller than our model grid. Emissions of primary sulfate are a standard option in many aerosol models (e.g., Adams and Seinfeld, 2002; Spracklen et al., 2005a; Stier et al., 2005), however the properties of the particles are very uncertain. Primary sulfate and carbonaceous (EC/OC) particles are emitted assuming lognormal modes, which are mapped onto the model size bins. We emit primary sulfate at the rate (2.5\% of $\mathrm{SO}_{2}$ emissions) and using the size distribution suggested by AEROCOM (road transport: number median radius, $r=15 \mathrm{~nm}, \sigma=1.8$; shipping, industry and power-plant emissions: $r=500 \mathrm{~nm}$, $\sigma=2.0$; wildfire and biofuel: $r=40 \mathrm{~nm}, \sigma=1.8$; volcanic emissions: $50 \%$ at $r=15 \mathrm{~nm}$ and $50 \%$ at $r=40 \mathrm{~nm}$, $\sigma=1.8$ ). For EC/OC emissions we use the emission size dstribution suggested by Stier et al. (2005) (fossil fuel emissions: $r=30 \mathrm{~nm}, \sigma=1.59$, wildfire and biofuel emissions: $r=75 \mathrm{~nm}$ and $\sigma=1.59$ ).

2. Experiment BHN includes identical primary emissions to PRI, but additionally it includes particle formation assuming binary homogeneous $\mathrm{H}_{2} \mathrm{SO}_{4}-\mathrm{H}_{2} \mathrm{O}$ nucleation using the paramaterization of Kulmala et al. (1998a).

3. Experiments PRICAR and PRISUL test the sensitivity of the model to uncertainty in the assumed size distribution of the primary emissions. Experiment PRICAR

\footnotetext{
${ }^{1}$ Available at: http://nansen.ipsl.jussieu.fr/AEROCOM/
}

uses the AEROCOM size distribution for emissions of EC/OC particles (Dentener et al., 2006), emitting $\mathrm{EC} / \mathrm{OC}$ particles at about half the diameter of experiment PRI (fossil fuel: $r=15 \mathrm{~nm}, \sigma=1.8$, biofuel and wildfire: $r=40 \mathrm{~nm}, \sigma=1.8$ ) and thereby increasing the emitted EC/OC number by about a factor 8 . Experiment PRISUL assumes that anthropogenic primary sulfate particles (transport, shipping, industry and powerplant emissions) are emitted at the size distribution according to Adams and Seinfeld (2003) (15\% of emitted mass at $r=5 \mathrm{~nm}, \sigma=1.6,85 \%$ at $r=35 \mathrm{~nm}, \sigma=2.0$ ).

4. Experiments ACT and $\mathrm{KIN}$ are as experiment BHN, but additionally they include an empirical particle formation mechanism (Kulmala et al., 2006; Sihto et al., $2006)$ in the BL. This mechanism is based on analysis of surface particle formation events. The formation rate $\left(J_{1}\right)$ of 1 -nm particles is given by:

$J_{1}=A\left[\mathrm{H}_{2} \mathrm{SO}_{4}\right]^{M}$

where $A$ is the nucleation coefficient. The value of $M$ has been found to vary between 1 and 2 and $A$ varies spatially and temporally, for reasons which are not known. We perform model simulations for both $M=1$ (activation mechanism, ACT) and $M=2$ (kinetic mechanism, KIN) and with a range of nucleation coefficients. In each model experiment the magnitude of the nucleation coefficient is fixed globally.

The particle formation rate at $3 \mathrm{~nm}\left(J_{3}\right)$ is obtained from $J_{1}$ and the equation of Kerminen and Kulmala (2002):

$J_{3}=J_{1} \exp \left(-0.153 \frac{\mathrm{CS}^{\prime}}{\mathrm{GR}}\right)$,

where $\mathrm{CS}^{\prime}$ is the reduced condensation sink $\left(\mathrm{m}^{-2}\right)$ and GR $\left(\mathrm{nm} \mathrm{h}^{-1}\right)$ is the cluster growth rate (Spracklen et al., 2006). GR is assumed to be constant between $1 \mathrm{~nm}$ and $3 \mathrm{~nm}$ and is calculated from the gas-phase sulfuric acid concentration. Newly formed particles are added to the model at $3 \mathrm{~nm}$ diameter. A full description of this mechanism in the GLOMAP model is described in Spracklen et al. (2006).

The empirical particle formation mechanism is based on observation of particle formation events made at the surface and there is some evidence to suggest that formation events are less likely in the lower FT (Heintzenberg et al., 2008; O'Dowd et al., 2009). Additionally, observations of the vertical profile of $\mathrm{CN}$ number concentrations typically show maxima at the surface and in the UT and a minimum in the lower FT (Clarke and Kapustin, 2002; Schröder et al., 2002; Singh et al., 2002). Applying the empirical particle formation mechanism throughout the depth of the troposphere in our model does not capture this observed profile and results in overprediction of $\mathrm{CN}$ concentrations in the lower FT (Metzger et al., 2010). For this reason, as in earlier work 
Table 1. Simulated annual mean (median) surface $\mathrm{CN}(D p>3 \mathrm{~nm})$ concentrations (at ambient temperature and pressure) for the year 2000 for model experiments with different primary emissions and particle formation (see Sect. 2.2 for details).

\begin{tabular}{|c|c|c|c|c|c|}
\hline \multirow{2}{*}{$\begin{array}{l}\text { Experiment } \\
\text { Name }\end{array}$} & \multicolumn{2}{|c|}{ Size distribution of primary emissions } & \multirow{2}{*}{ Nucleation mechanisms } & \multicolumn{2}{|c|}{ Surface mean (median) CN } \\
\hline & $\mathrm{EC} / \mathrm{OC}$ & Sulfate & & Ocean $/ \mathrm{cm}^{-3}$ & Land $/ \mathrm{cm}^{-3}$ \\
\hline PRI & Stier et al. (2005) & AEROCOM & None & $105(30)$ & $642(107)$ \\
\hline BHN & Stier et al. (2005) & AEROCOM & BHN & $352(252)$ & $952(604)$ \\
\hline PRICAR & AEROCOM & AEROCOM & BHN & $495(265)$ & $2230(839)$ \\
\hline PRISUL & Stier et al. (2005) & Adams and Seinfeld (2003) & BHN & $595(267)$ & $2282(721)$ \\
\hline ACT1 & Stier et al. (2005) & AEROCOM & $\begin{array}{l}\text { BHN + Activation } \\
\left(A=2 \times 10^{-7} \mathrm{~s}^{-1}\right)\end{array}$ & $474(323)$ & $1262(703)$ \\
\hline ACT2 & Stier et al. (2005) & AEROCOM & $\begin{array}{l}\text { BHN + Activation } \\
\left(A=2 \times 10^{-6} \mathrm{~s}^{-1}\right)\end{array}$ & $729(483)$ & $1743(868)$ \\
\hline ACT3 & Stier et al. (2005) & AEROCOM & $\begin{array}{l}\text { BHN + Activation } \\
\left(A=2 \times 10^{-5} \mathrm{~s}^{-1}\right)\end{array}$ & $1157(660)$ & $2653(1018)$ \\
\hline KIN1 & Stier et al. (2005) & AEROCOM & $\begin{array}{c}\text { BHN + Kinetic } \\
\left(A=2 \times 10^{-13} \mathrm{~cm}^{3} \mathrm{~s}^{-1}\right)\end{array}$ & $557(323)$ & $1498(725)$ \\
\hline KIN2 & Stier et al. (2005) & AEROCOM & $\begin{array}{c}\text { BHN + Kinetic } \\
\left(A=2 \times 10^{-12} \mathrm{~cm}^{3} \mathrm{~s}^{-1}\right)\end{array}$ & $798(426)$ & $2003(813)$ \\
\hline KIN3 & Stier et al. (2005) & AEROCOM & $\begin{array}{c}\text { BHN + Kinetic } \\
\left(A=2 \times 10^{-11} \mathrm{~cm}^{3} \mathrm{~s}^{-1}\right)\end{array}$ & $1181(550)$ & $2764(878)$ \\
\hline
\end{tabular}

(Spracklen et al., 2006, 2008), we restrict the empirical particle formation mechanism to the BL while allowing BHN to occur above (which results in particle formation in the UT).

\section{Simulation of surface $\mathrm{CN}$ number concentrations}

Simulated surface $\mathrm{CN}$ (diameter $>3 \mathrm{~nm}$ ) concentrations for the different experiments described in Sect. 2.2 are shown in Table 1 and Fig. 1. With no particle formation (PRI), surface annual mean (median) $\mathrm{CN}$ concentrations are $105(30) \mathrm{cm}^{-3}$ over the oceans and $640(107) \mathrm{cm}^{-3}$ over the continents. The greater simulated concentrations over the continents are due to primary anthropogenic emissions. Secondary particle formation by binary homogeneous nucelation (BHN) increases surface mean (median) $\mathrm{CN}$ concentrations by a factor 3.3 (8.4) over the oceans and factor 1.5 (5.7) over the continents. The absolute increase in mean $\mathrm{CN}$ at the surface due to BHN is relatively uniform across the globe (average of $250 \mathrm{~cm}^{-3}$ over oceans and $310 \mathrm{~cm}^{-3}$ over continental regions). This is because the secondary source of particles from BHN is largely in the UT and somewhat independent of $\mathrm{SO}_{2}$ sources at the surface (Raes et al., 2000). Increasing the number emission of primary EC/OC particles (PRICAR) further increases (over experiment BHN) mean (median) surface $\mathrm{CN}$ concentrations by a factor 1.4 (1.1) over the oceans and a factor 2.3 (1.4) over the continents. Increasing the number emissions of primary sulfate particles (PRISUL) increases $\mathrm{CN}$ concentrations by a factor 1.7 (1.1) over the oceans and a factor 2.4 (1.2) over the continents. The empirical BL particle formation scheme (with $M=1$ and $k=2 \times 10^{-6} \mathrm{~s}^{-1}$ ) increases mean (median) surface $\mathrm{CN}$ concentrations (over experiment BHN) by a factor of 2.1 (1.9) over the oceans and by a factor of 1.8 (1.4) over the continents. Surface CN concentrations are sensitive to the nucleation coefficient used: a factor 100 change in the BL nucleation coefficient ( $A$ in Eq. 1) changes $J_{1}$ by a factor 100 and increases the surface $\mathrm{CN}$ concentration by a factor of 2.3. In contrast, surface $\mathrm{CN}$ are relatively insensitive to changes in the BHN nucleation rate, changing by less than $40 \%$ for factor 100 change in the BHN rate (Spracklen et al., 2005b). This is because BHN occurs primarily in the UT and coagulation that occurs during transport and mixing of air to the surface reduces the sensitivity of surface $\mathrm{CN}$ to changes in BHN rate. The sensitivity of surface $\mathrm{CN}$ concentrations to the $\mathrm{BL}$ particle formation rate allows us to use observed $\mathrm{CN}$ concentrations and a global model to give an estimate of the surface nucleation rate as we show below (Sect. 4.2).

\section{Model evaluation}

\subsection{The $\mathrm{CN}$ dataset}

To evaluate the model we compiled a dataset of surface $\mathrm{CN}$ number concentrations recorded at 36 sites around the world. The locations of the sites are shown in Fig. 2 and Table 2. We broadly classified the sites into FT, MBL and continental BL. We did not include any sites within urban environments because the resolution of our model is not sufficient to resolve urban-scale pollution. We only included sites which have recorded $\mathrm{CN}$ concentrations for at least a 12 month period. 
(a)

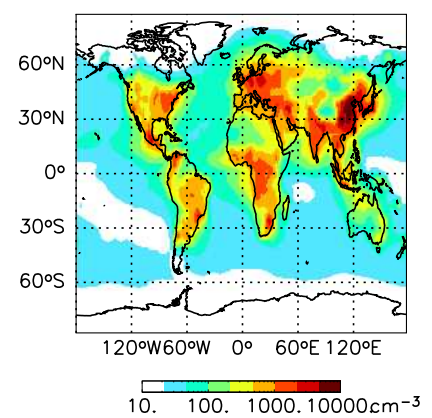

(d)

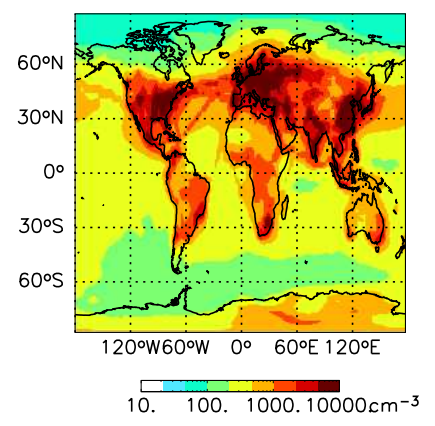

(b)

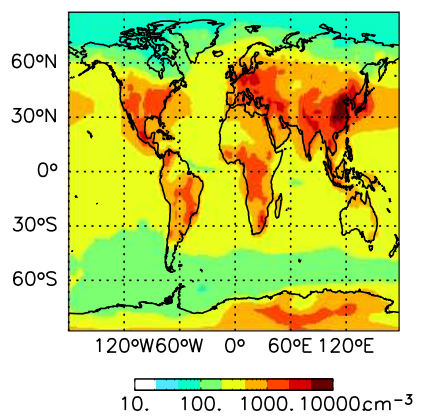

(e)

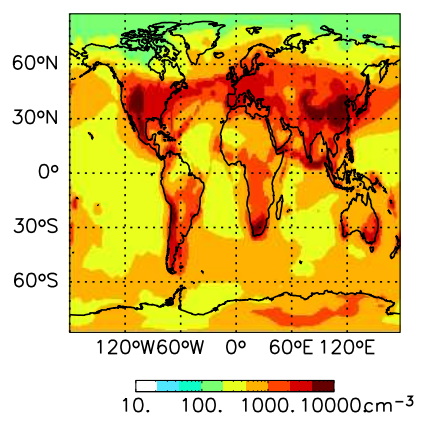

(c)

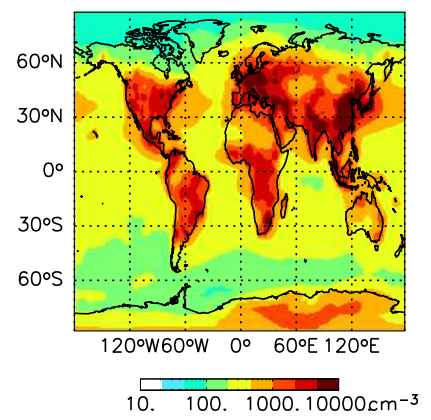

$(f)$

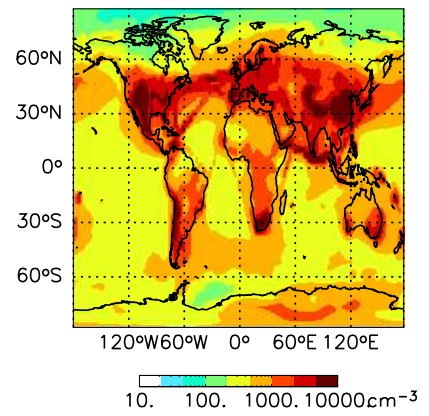

Fig. 1. Simulated surface annual mean $\mathrm{CN}(\mathrm{Dp}>3 \mathrm{~nm})$ concentrations (at ambient temperature and pressure) for the different experiments described in Table 1: (a) Primary emissions only (PRI), (b) Primary emissions and binary homogeneous nucleation (BHN), (c) BHN and increased primary EC/OC (PRICAR), (d) BHN and increased primary sulfate (PRISUL), (e) Primary emissions, BHN and activation particle formation (ACT2), (f) Primary emissions, BHN and kinetic particle formation (KIN2).

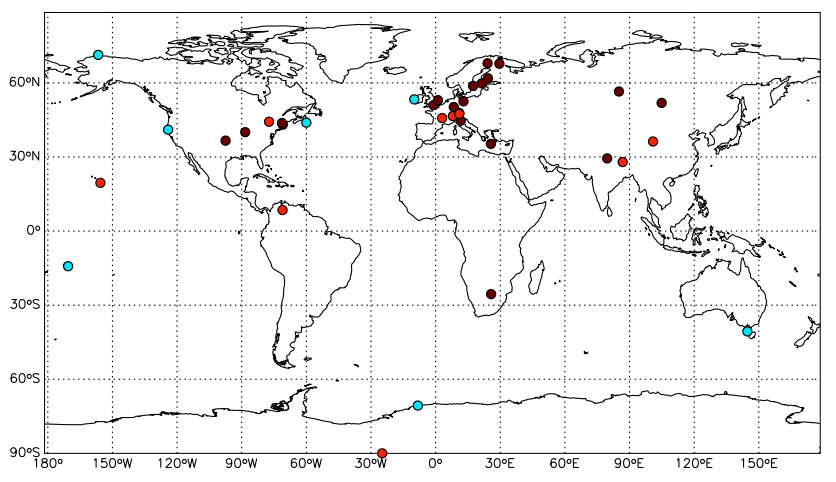

Fig. 2. Location of observation sites used in this analysis classified as in Table 2: FT (red), MBL (blue), continental BL (brown).

At sites with more than 12 months of data we report monthly mean and median cooncentrations as an average over the multiannual dataset. The time period of observations used at each site is shown in Table 2. To give an indication of the interannual variability in the observations we report the standard deviation in monthly mean $\mathrm{CN}$ concentrations at sites where there are 4 or more years of data available.

Observations of $\mathrm{CN}$ were made either using condensation particle counters (CPCs), scanning mobility particle sizers
(SMPS), differential mobility particle sizers (DMPS) or Diffusion Aerosol Spectroscopes (DAS). CPCs record total particle number concentration typically for sizes greater than $3 \mathrm{~nm}$ or $10 \mathrm{~nm}$ in diameter. SMPS and DMPS record the particle size distribution at sizes greater than either $3 \mathrm{~nm}$ or $10 \mathrm{~nm}$ in diameter. From the observed size distribution a CN concentration was calculated. We compared model experiments for each site using the same lower cutoff diameter as available from the observations. All $\mathrm{CN}$ concentrations are reported at ambient temperature and pressure.

All the MBL sites in this analysis are at coastal locations which are influenced to some extent by continental emissions. Samoa, in the tropical Pacific and Neumayer, on the Antarctic coast, probably experience the minimum continental and anthropogenic influence. We did not screen the data in an attempt to remove continental influence (e.g., Reade et al., 2006) as this complicates analysis with a 3-D Eulerian model.

High altitude sites located near the top of mountains are often influenced by thermal winds or forced convection resulting in diurnal cycles in aerosol (Weingartner et al., 1999; Venzac et al., 2009). Additionally, diurnal and seasonal variation of BL height means mountain sites can be located in either the BL or FT at different times of the day or year. For these reasons the data from high altitude sites may not 
Table 2. Observation sites used in this analysis.

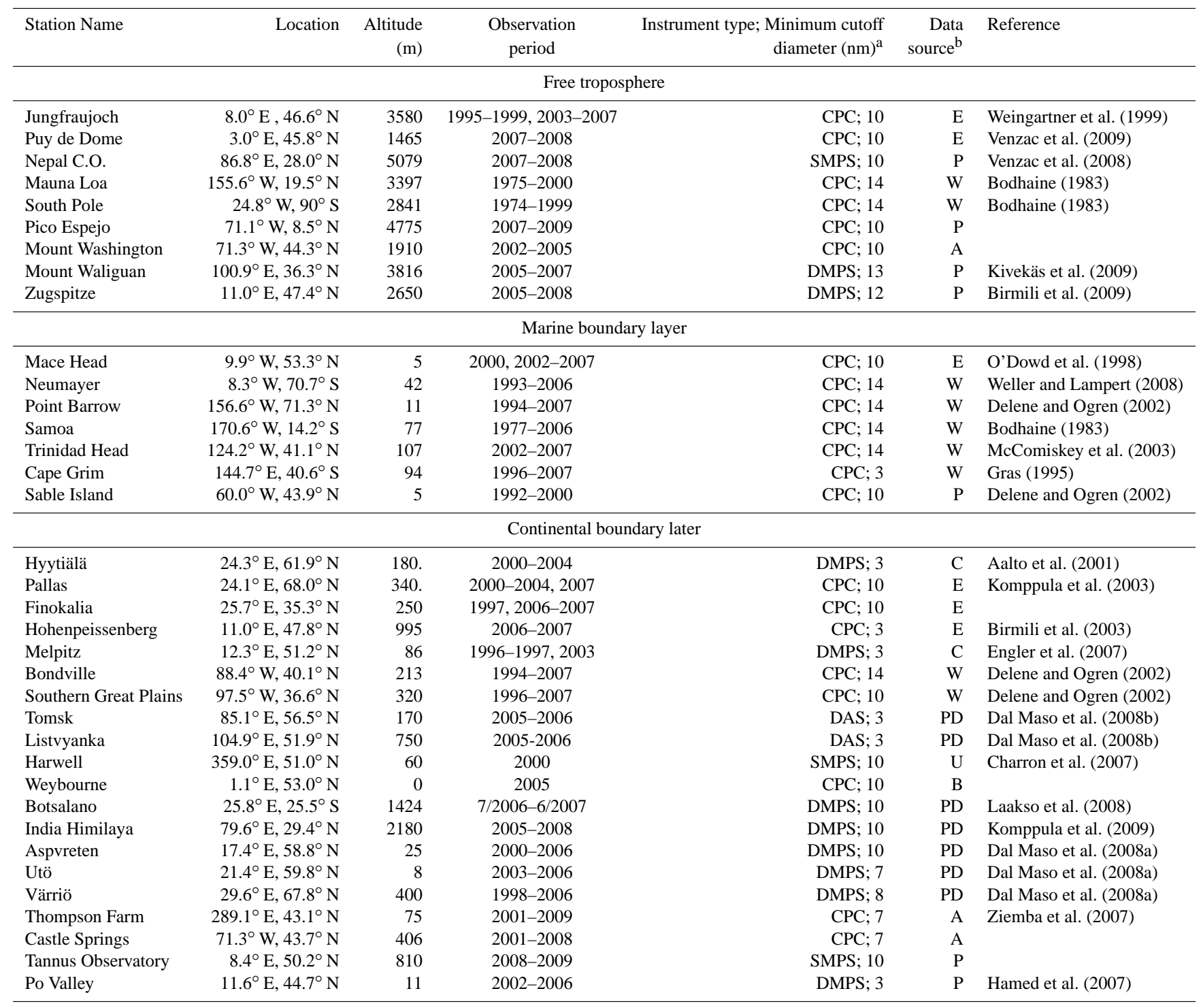

${ }^{a}$ CPC: condensation particle counter; SMPS : scanning mobility particle sizer; DMPS: differential mobility particle sizer; DAS:Diffusion Aerosol Spectroscope. ${ }^{b}$ AIRMAP, http://airmap.unh.edu/data/(A); BADC, http://badc.nerc.ac.uk/home/ (B); CREATE, http://tarantula.nilu. no/projects/ccc/create/ (C);

EBAS, http://ebas.nilu.no. (E); Personal communication (P); Published data, see citation (PD); UK National Air Quality Archive, http://www.airquality.co.uk/ (U); World Data Centre for Aerosols (WDCA), http://wdca.jrc.ec.europa.eu/ (W).

represent background FT conditions without detailed screening which was not performed here. Nethertheless, the model does simulate variations in BL height though they have not been evaluated specifically at the locations analysed in this study.

We linearly interpolate the model to the horizontal location of the observations. Where sub-grid topography means that the altitude above sea-level of the observation site is not within $500 \mathrm{~m}$ of the grid-point elevation of the model surface level (TOMCAT uses hybrid $\sigma$-pressure coordinates), we interpolate the model in the vertical to match the altitude of the observations.

\subsection{Global analysis of annual mean $\mathrm{CN}$ number concentrations}

Figure 3 compares simulated and observed annual mean $\mathrm{CN}$ number concentrations. Observed annual mean $\mathrm{CN}$ 

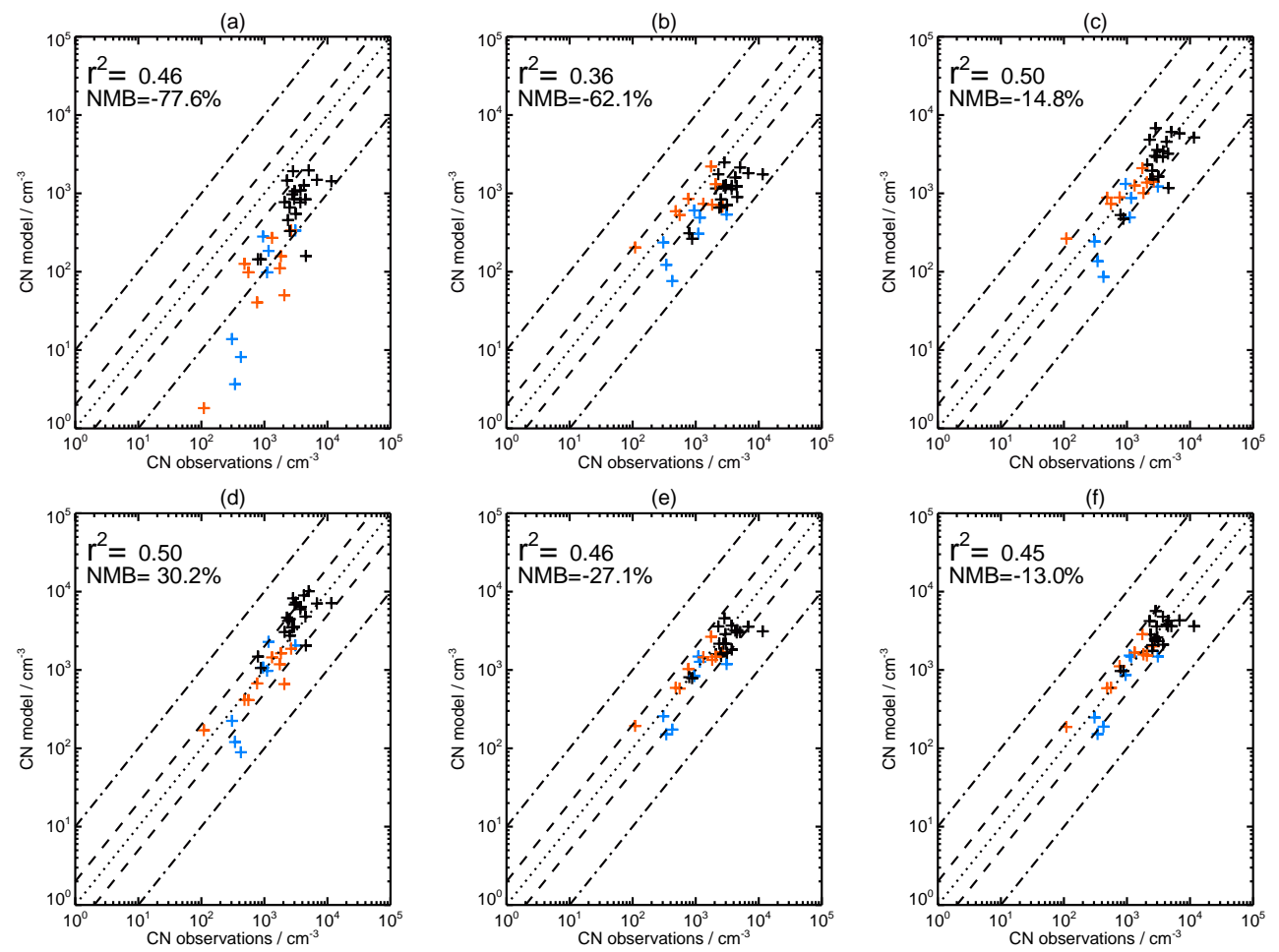

Fig. 3. Scatterplot of simulated (GLOMAP) versus observed annual mean $\mathrm{CN}$ concentrations (at ambient temperature and pressure) for the sites shown in Fig. 2. Sites are classified as FT (red), MBL (blue) and continental BL (black) as shown in Table 2. The different model experiments are described in Table 1: (a) Primary emissions only (PRI), (b) Primary emissions and binary homogeneous nucleation (BHN), (c) BHN and increased primary EC/OC (PRICAR), (d) BHN and increased primary sulfate (PRISUL), (e) Primary emissions, BHN and activation particle formation (ACT2), (f) Primary emissions, BHN and kinetic particle formation (KIN2). The Pearson correlation coefficients $\left(R^{2}\right)$ and normalised mean bias (NMB) are shown. The dotted line represents the 1:1 relation and the dashed lines factor of 2 and 10 deviations.

concentrations at MBL sites are typically $300-2000 \mathrm{~cm}^{-3}$. The lowest concentrations are observed at Samoa in the tropical MBL $\left(300 \mathrm{~cm}^{-3}\right)$, coastal Antarctica $\left(350 \mathrm{~cm}^{-3}\right)$ and Point Barrow in the Arctic $\left(450 \mathrm{~cm}^{-3}\right)$. These 3 sites are likely to be the MBL sites with the least anthropogenic influence. The mid-latitude MBL sites have mean CN concentrations of between $1000 \mathrm{~cm}^{-3}$ and $2000 \mathrm{~cm}^{-3}$, while even greater concentrations are observed at Mace Head $\left(3000 \mathrm{~cm}^{-3}\right)$. The higher concentrations at mid-latitude MBL sites is possibly because they are more heavily influenced by continental and anthropogenic aerosol sources. Mace Head is influenced by local nucleation events driven by iodine compounds (O'Dowd et al., 2002a,b) which likely explains the higher concentrations observed at this site. We did not filter out a continental influence so the MBL CN concentrations we report at these sites may not be representative for the open ocean. In the FT, annual mean $\mathrm{CN}$ concentrations are typically $500-2000 \mathrm{~cm}^{-3}$. Lower concentrations are observed at the South Pole in Antarctica $\left(100 \mathrm{~cm}^{-3}\right)$. Observed $\mathrm{CN}$ concentrations at continental BL sites are up to an order of magnitude greater than in the FT or MBL, spanning $800 \mathrm{~cm}^{-3}$ to $7000 \mathrm{~cm}^{-3}$.
We quantify the bias between model and observations as a normalised mean bias $\left(\mathrm{NMB}=100 \times \sum_{i=1}^{n}\left(S_{i}-O_{i}\right) / \sum_{i=1}^{n} O_{i}\right.$, where $S_{i}$ is the simulated annual mean $\mathrm{CN}$ concentration and $O_{i}$ is the observed multi-year annual mean $\mathrm{CN}$ concentration at site $i$ ) shown in Table 3. The long sampling period (monthly and annual means) used in this analysis means that meteorological variability between specific years of observation and the year 2000 simulation is not likely to be a significant factor in the comparison.

The experiment with natural and anthropogenic primary particulate emissions but no secondary particle formation (PRI) captures the spatial pattern of $\mathrm{CN}$ concentrations relatively well $\left(R^{2}=0.46\right)$ but underestimates concentrations at all sites (slope of the linear regression, $m=0.29$, $\mathrm{NMB}=-78 \%$ ). Simulated concentrations at continental BL sites are underpredicted by a factor of $2-10$, and FT and MBL sites are underpredicted by up to a factor of 10 or more.

Including binary homogeneous nucleation in the model (BHN) increases simulated BL CN concentrations by 200 $400 \mathrm{~cm}^{-3}$ and FT CN by up to $1000 \mathrm{~cm}^{-3}$ but results in only a modest reduction in model bias across all sites $(m=0.32$, 
Table 3. Normalised mean bias between observed and simulated CN concentrations. Model experiments are described in Table 1, locations and time periods of the observations are shown in Table 2.

\begin{tabular}{lcccccccccc}
\hline Stations & & \multicolumn{8}{c}{ Model experiments } \\
& PRI & BHN & PRICAR & PRISUL & ACT1 & ACT2 & ACT3 & KIN1 & KIN2 & KIN3 \\
\hline All & $-77 \%$ & $-62 \%$ & $-15 \%$ & $30 \%$ & $-45 \%$ & $-27 \%$ & $10 \%$ & $-33 \%$ & $-13 \%$ & $35 \%$ \\
FT & $-88 \%$ & $-25 \%$ & $-6 \%$ & $-18 \%$ & $-9 \%$ & $14 \%$ & $53 \%$ & $5 \%$ & $28 \%$ & $68 \%$ \\
MBL & $-85 \%$ & $-61 \%$ & $-28 \%$ & $11 \%$ & $-40 \%$ & $-12 \%$ & $23 \%$ & $-27 \%$ & $-3 \%$ & $21 \%$ \\
BL & $-74 \%$ & $-66 \%$ & $-15 \%$ & $46 \%$ & $-48 \%$ & $-29 \%$ & $12 \%$ & $-35 \%$ & $-13 \%$ & $31 \%$ \\
\hline
\end{tabular}

$\mathrm{NMB}=-62 \%)$. Simulated concentrations are most improved at FT sites $(\mathrm{NMB}=-25 \%)$ and annual mean particle number at FT sites are mostly predicted within a factor of 2 . $\mathrm{CN}$ concentrations at MBL sites are still underpredicted $(\mathrm{NMB}=-61 \%)$. However, annual mean $\mathrm{CN}$ concentrations are best simulated at Samoa and Neumayer which are the most remote MBL sites in this analysis.

Increasing the number emission of primary anthropogenic particulate emissions (by reducing the assumed diameter of the emissions) increases simulated $\mathrm{BL} \mathrm{CN}$ concentrations by as much as $10000 \mathrm{~cm}^{-3}$. The impact in the BL is regionally dependent: at sites close to anthropogenic sources (e.g., Finokalia, Hohenpeissenberg, Bondville, South Great Plains) simulated $\mathrm{CN}$ increases by up to a factor of 2.5, whereas at remote BL sites (e.g., South Pole, Point Barrow, Samoa, Cape Grim) they increase by less than $30 \%$. Increasing EC/OC number emission (PRICAR) results in a smaller model bias $(m=0.93, \mathrm{NMB}=-15 \%)$ whereas increasing primary sulfate (PRISUL) results in model overprediction $(m=1.47, \mathrm{NMB}=30 \%)$. Such a large increase in simulated $\mathrm{CN}$ concentrations due to primary emissions has been seen in previous work such as Pierce and Adams (2009).

Including BL particle formation increases annual mean $\mathrm{CN}$ concentrations at BL sites by several thousand $\mathrm{cm}^{-3}$, similar to that simulated by increasing anthropogenic primary emissions. With the activation (ACT) particle formation mechanism, model bias varies from $-45 \%$ to $10 \%$ with the best match between model and observations occurring using a nucleation coefficient of between $A=2 \times 10^{-6}$ and $A=2 \times 10^{-5} \mathrm{~s}^{-1}$. With the kinetic (KIN) particle formation mechanism, model bias varies between $-34 \%$ and $35 \%$ with the best match occurring when $A=2 \times 10^{-12} \mathrm{~cm}^{3} \mathrm{~s}^{-1}$. The optimum nucleation rate coefficients in our model lie within the range of values calculated from detailed analysis of particle formation events: activation mechanism $A=3.3 \times 10^{-8} \mathrm{~s}^{-1}-3.5 \times 10^{-4} \mathrm{~s}^{-1}$ (Riipinen et al., 2007); kinetic mechanism $A=2.4 \times 10^{-15} \mathrm{~cm}^{3} \mathrm{~s}^{-1}$ $1.3 \times 10^{-10} \mathrm{~cm}^{3} \mathrm{~s}^{-1}$ (Riipinen et al., 2007; Kuang et al., 2008).

Our analysis provide support for previous work (Riipinen et al., 2007; Kuang et al., 2008) that the magnitude of the BL nucleation rate coefficient varies spatially. Ob- served CN concentrations at Arctic and boreal forest sites (Pallas and Hyytiälä) are well matched by the model with $A=2 \times 10^{-6} \mathrm{~s}^{-1}(M=1)$ or $2 \times 10^{-13} \mathrm{~cm}^{3} \mathrm{~s}^{-1}(M=2)$. Sites in the Midwest US (Bondville and South Great Plains) would require a nucleation coefficient greater than $A=2 \times 10^{-5} \mathrm{~s}^{-1}$ $(M=1)$ to match observed $\mathrm{CN}$. The reason for variability in the nucleation rate coefficient is unknown, but could include varying concentrations of other atmospheric species that can stabilise sulfate clusters. It has been suggested that organic species may be a key candidate (Verheggen et al., 2007; Bonn et al., 2008).

The simulated spatial pattern of annual mean $\mathrm{CN}$ concentrations is not greatly improved through increasing the number emission of primary particles or including BL particle formation. Previous studies, using a smaller dataset than we compiled here, have also shown that it is difficult to constrain particle formation and primary emissions using annual mean particle number concentrations. To provide a stronger constraint on primary emissions and particle formation we therefore examined the observed seasonal cycle of particle number.

\subsection{Accounting for the seasonal cycle in $\mathrm{CN}$}

Figures 4, 5 and 6 show the seasonal cycle of observed and simulated CN concentrations at FT, MBL and continental BL sites. At many BL locations a pronounced seasonal cycle is observed, with summer-time CN concentrations exceeding winter-time concentrations by a factor of $2-$ 10. For example, at Pallas, summertime $\mathrm{CN}$ concentrations are about $1250 \mathrm{~cm}^{-3}$ whereas wintertime concentrations are about $250 \mathrm{~cm}^{-3}$. Strong seasonal cycles also exist at some FT sites. At the South Pole summertime CN concentrations are about $250 \mathrm{~cm}^{-3}$ whereas wintertime concentrations are less than $20 \mathrm{~cm}^{-3}$. However, care has to taken in interpreting seasonal cycles at some FT sites due to the potential for contamination with uplifted BL air.

Table 4 shows the correlation coefficient between simulated and observed monthly mean $\mathrm{CN}$ concentrations for sites where monthly mean $\mathrm{CN}$ concentrations vary by more than a factor of 2 throughout the seasonal cycle. Figure 7 shows the average correlation coefficents for these sites calculated 

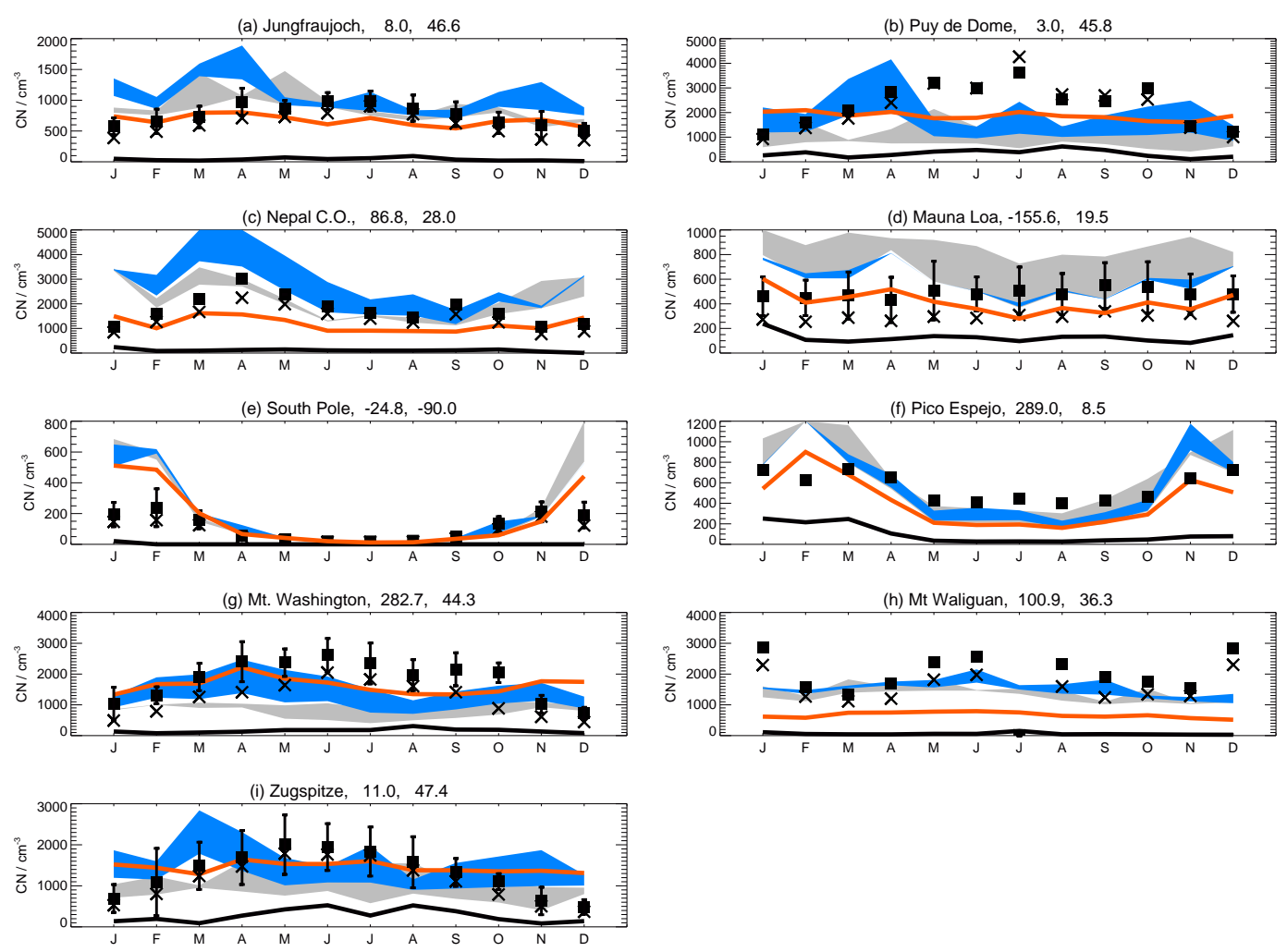

Fig. 4. Seasonal cycle of $\mathrm{CN}$ concentrations (at ambient temperature and pressure) at the FT sites shown in Table 2 . Solid squares show observed monthly mean concentrations, crosses show observed monthly median concentrations and vertical bars show the standard deviation of the observed monthly mean (displayed only where there are 4 or more years of observations). The model experiments are described in Table 1: Black line shows the model with primary particulate emissions only (PRI), bottom of grey shading shows model with primary emissions and BHN (BHN), top of grey shading shows model with BHN and increased EC/OC number emission (PRICAR). Red line shows model with BHN and increased primary sulfate number emission (PRISUL). Blue shading shows model with primary emissions, BHN and activation BL particle formation, with the width of shading showing sensitivity to varying nucleation coefficients from $A=2 \times 10^{-7} \mathrm{~s}^{-1}$ (ACT1) to $A=2 \times 10^{-5} \mathrm{~s}^{-1}$ (ACT3).

separately for FT, MBL and continental BL sites.

The simulation with only primary particulate emissions (PRI) does not capture the observed seasonal cycle shown by the poor correlation coefficient between simulated and observed monthly mean CN concentrations at FT $\left(R^{2}=0.09\right)$, $\operatorname{MBL}\left(R^{2}=0.14\right)$ and continental BL sites $\left(R^{2}=0.11\right)$. This demonstrates that changes to the seasonal cycle of primary emissions and changes to meteorology, transport and deposition are not sufficient to explain the observed seasonal cycle in $\mathrm{CN}$ concentrations. The emission datasets for biofuel emissions do not include a seasonal dependance which may cause a problem for simulating aerosol at some sites in Europe where wood burning is a much more important emission source in winter. However, the cycle of wood burning emissions (higher in winter) is opposite to that in observed $\mathrm{CN}$ concentrations (higher in summer) so this can not be an explanation for the incorrectly simulated seasonal cycle.

With BHN the model better captures the observed seasonal cycle at some MBL (e.g., Neumayer) and FT sites (e.g., South Pole, Mt. Washington) resulting in an improved correlation in both the FT $\left(R^{2}=0.26\right)$ and MBL $\left(R^{2}=0.36\right)$. While winter-time concentrations are relatively well simulated, at some BL sites (e.g., Point Barrow, Hyytiälä and Pallas) underprediction during summer months results in a poorly represented seasonal cycle in the continental BL $\left(R^{2}=0.1\right)$. Increasing anthropogenic primary emissions degrades model representation of the seasonal cycle in the FT (PRICAR, $R^{2}=0.12$, PRISUL, $R^{2}=0.22$ ) and MBL (PRICAR, $R^{2}=0.21$, PRISUL, $R^{2}=0.36$ ), while slightly improving simulation in the continental BL (PRICAR, $R^{2}=0.14$, PRISUL, $R^{2}=0.18$ ). The empirical BL nucleation mechanism results in better simulation of the seasonal cycle improving the simulated seasonal cycle at continental $\mathrm{BL}$ sites (ACT2, $R^{2}=0.25$; KIN2 $R^{2}=0.30$ ) whilst maintaining or improving representation of the seasonal cycle in the FT (ACT2, $R^{2}=0.27$; KIN2 $R^{2}=0.36$ ) and MBL (ACT2, $\left.R^{2}=0.34 ; \mathrm{KIN} 2 R^{2}=0.43\right)$. 

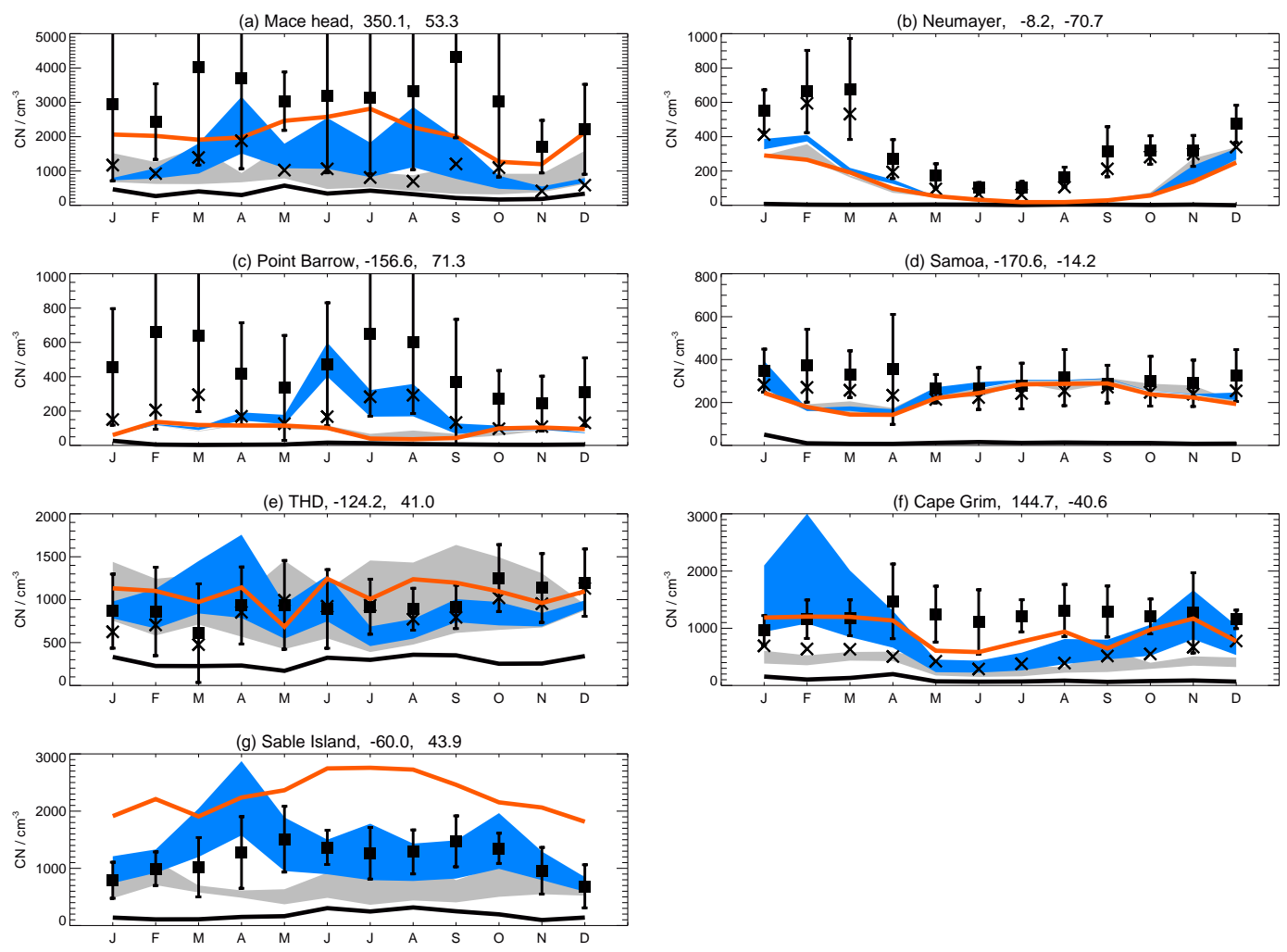

Fig. 5. As for Fig. 4 but for MBL sites.

\subsection{Additional remote marine $\mathrm{CN}$ measurements}

To extend the evaluation of the model to the remote MBL we use the dataset of Heintzenberg et al. (2000) who compiled observations from several field campaigns including ACE-1, ACE-2, ACE-Asia and INDOEX. Heintzenberg et al. (2000) fitted observed aerosol size distributions with two lognormal modes and gridded the observations into $15^{\circ}$ latitude bands. The different field campaigns used a range of sampling instruments with lower cutoff diameters ranging from $3 \mathrm{~nm}$ to $12 \mathrm{~nm}$, but this information was not captured by the analysis. Additionally, the limited number of field campaigns available within certain latitude bands means that the dataset may not adequately represent $\mathrm{CN}$ concentrations within these regions. For this reason we only make qualitative comparisons between the dataset and our simulations.

Figure 8 shows $\mathrm{CN}$ concentrations from the Heintzenberg et al. (2000) dataset compared with our model. We plot simulated CN12 (diameter $>12 \mathrm{~nm}$ ), which over the oceans is virtually identical to simulated $\mathrm{CN} 3$ (diameter $>3 \mathrm{~nm}$ ), except when BL particle formation is included in the model. For this experiment we plot both $\mathrm{CN} 3$ and $\mathrm{CN} 12$.

With primary emissions only (PRI) the model underestimates $\mathrm{CN}$ concentrations at all latitudes except $30^{\circ}-45^{\circ} \mathrm{N}$. When binary homogeneous nucleation is included (BHN) the model still underpredicts $\mathrm{CN}$ concentrations in the South-

ern Hemisphere (between $15^{\circ} \mathrm{S}$ and $75^{\circ} \mathrm{S}$ ) and Arctic (between $75^{\circ} \mathrm{N}$ and $90^{\circ} \mathrm{N}$ ) oceans while either well simulating or overpredicting $\mathrm{CN}$ elsewhere in the Northern Hemisphere. Such underprediction in the Southern Hemisphere is a consistent feature of global aerosol models (Easter et al., 2004; Spracklen et al., 2005a,b; Pierce and Adams, 2006; Pierce et al., 2007; Trivitayanurak et al., 2008; Wang et al., 2009). Underprediction of $\mathrm{CN}$ above $75^{\circ} \mathrm{N}$ is likely due to the model not well simulating the transport of anthropogenic pollution to the Arctic (Korhonen et al., 2008). Increasing the number emission from primary anthropogenic sources results in overprediction of $\mathrm{CN}$ between $15^{\circ} \mathrm{N}$ and $60^{\circ} \mathrm{N}$, while the underprediction of $\mathrm{CN}$ persists in the Southern Hemisphere and Arctic. Including BL particle formation increases simulated $\mathrm{CN}$, particularly in regions of $\mathrm{SO}_{2}$ emissions from shipping and DMS emissions from the ocean. In the Southern Hemisphere, BL particle formation scheme improves the simulation of $\mathrm{CN}$, whereas in the Northern Hemisphere it results in overprediction of $\mathrm{CN}$ except in the Arctic where the model underprediction of $\mathrm{CN}$ remains. Emissions of ultrafine sea-spray (Mårtensson et al., 2003), not included in this work, may be another explanation for underpredition of $\mathrm{CN}$ in the Southern Ocean (Pierce and Adams, 2006). 

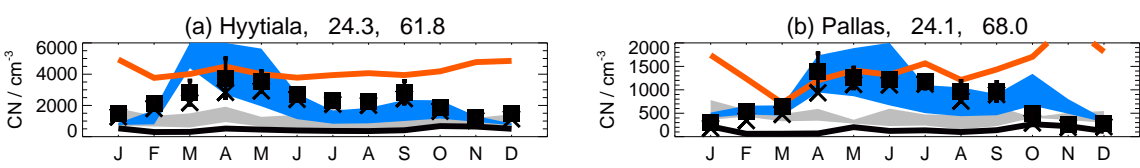

(d) Hohenpeissenberg, $11.0,47.8$

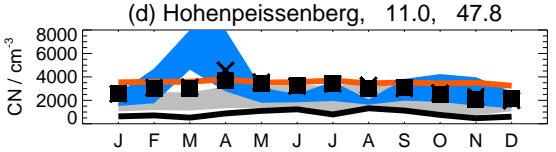

(g)SGP, $-97.5, \quad 36.6$
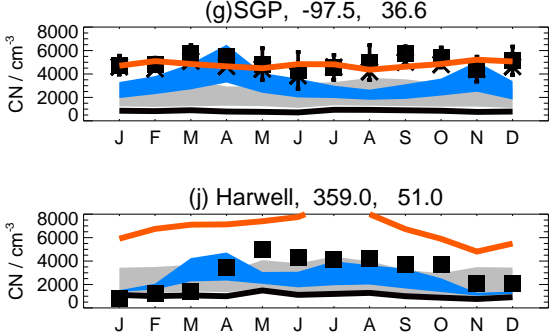

(m) India Himilaya, $79.6, \quad 29.4$

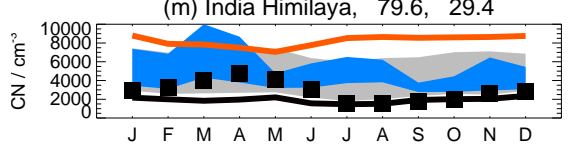

(p) Varrio, 29.6, 67.8

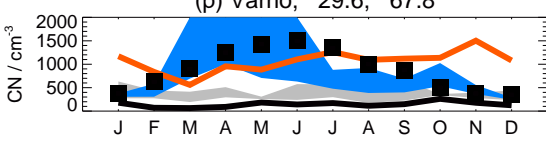

(s) Taunus Observatory, $\quad 8.4, \quad 50.2$

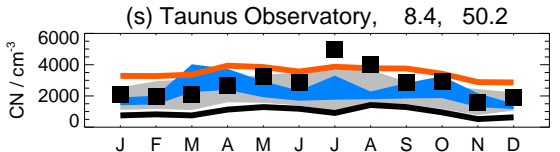

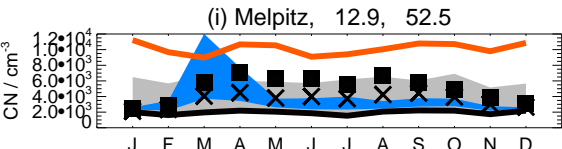

(h)Tomsk, 85.1, 56.5
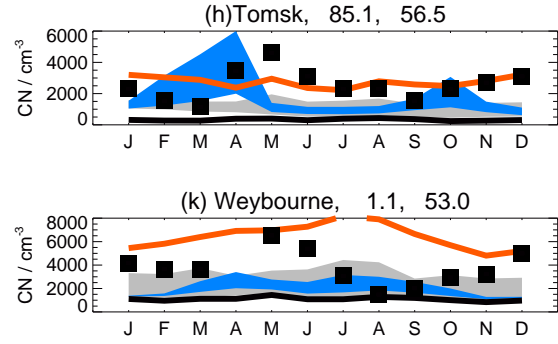

(n) Aspvreten, $17.4, \quad 58.8$

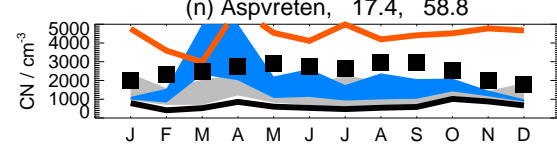

(q) Thompson Farm, 289.1, 43.1

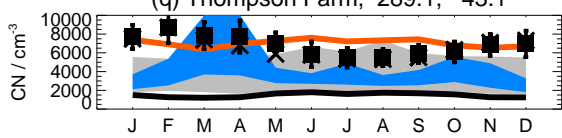

(t) Po Valley, 11.6, 44.7

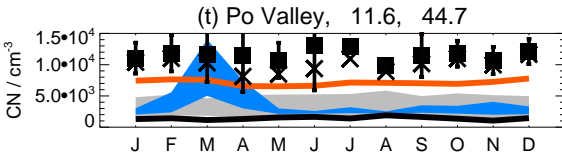

(c) Finokalia, 25.7, 35.3

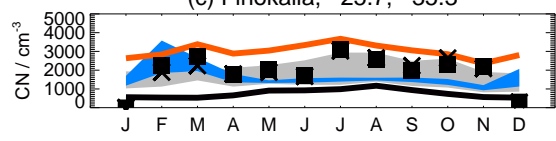

(f) Bondville, -88.4, 40.0

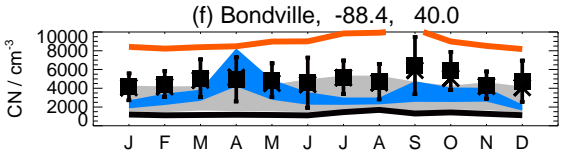

(i) Listvyanka, 104.9, 51.9

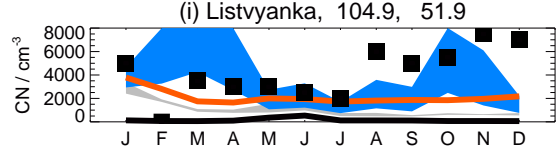

(I) Botsalano, 25.8, - 25.5

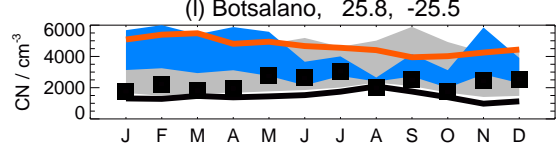

(o) Uto, 21.4, 59.8

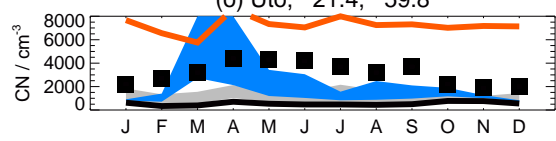

(r) Castle Springs, 288.7, 43.7

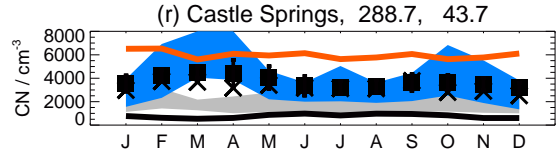

Fig. 6. As for Fig. 4 but for BL sites.

\section{Summary and conclusions}

We have synthesised total particle number $(\mathrm{CN})$ concentrations from surface sites around the world. A total of 36 sites met our minumum requirement of at least 12 months of $\mathrm{CN}$ data. The sites are located across both hemispheres in the free troposhere (FT), marine boundary layer (MBL) and continental boundary layer (BL). We found that $\mathrm{CN}$ concentrations (at ambient temperature and pressure) are typically $300-2000 \mathrm{~cm}^{-3}$ in the MBL and FT and $1000-10000 \mathrm{~cm}^{-3}$ in the continental BL.

We used the observations to evaluate the GLOMAP global aerosol microphysics model restricting our analysis to a comparison of monthly mean concentrations. Our aim was to evaluate the role of primary particulate emissions and new particle formation in controlling $\mathrm{CN}$ concentrations. We conducted a range of model simulations with different assumptions about primary anthropogenic particulate emissions and new particle formation.
Without secondary particle formation (primary particulate emissions only) the model greatly underpredicts observed $\mathrm{CN}$ concentrations $(\mathrm{NMB}=-78 \%)$. While the spatial pattern of observed $\mathrm{CN}$ was relatively well captured $\left(R^{2}=0.46\right)$ the model did not capture the seasonal cycle observed at FT $\left(R^{2}=0.09\right), \mathrm{MBL}\left(R^{2}=0.14\right)$ or continental $\mathrm{BL}$ sites $\left(R^{2}=0.11\right)$.

Including binary homogeneous nucleation of $\mathrm{H}_{2} \mathrm{SO}_{4}-\mathrm{H}_{2} \mathrm{O}$ (Kulmala et al., 1998a) in addition to primary emissions reduced model bias at FT sites $(\mathrm{NMB}=-25 \%)$ and improved the simulated seasonal cycle in the MBL $\left(R^{2}=0.36\right)$ and FT $\left(R^{2}=0.26\right)$. However, $\mathrm{CN}$ concentrations were still underpredicted in the continental BL with little improvement in model bias $(\mathrm{NMB}=-66 \%)$ or representation of the seasonal cycle $\left(R^{2}=0.1\right)$ at these sites.

There is considerable uncertainty in the size distribution of primary anthropogenic particulate emissions (which affects the particle number emitted for fixed mass) and previous studies have used a range of assumptions. We therefore evaluated the sensitivity of simulated $\mathrm{CN}$ to the uncertainty in 
Table 4. Correlation coefficient $\left(R^{2}\right)$ between observed and simulated monthly mean $\mathrm{CN}$ concentrations at sites where monthly mean concentrations vary by more than a factor of two throughout a seasonal cycle. Model experiments are described in Table 1 . The model run with the best correlation at each site is highlighted.

\begin{tabular}{|c|c|c|c|c|c|c|}
\hline Site & PRI & BHN & PRICAR & PRISUL & $\mathrm{ACT} 2$ & KIN2 \\
\hline \multicolumn{7}{|c|}{ Free troposphere } \\
\hline Puy de Dome & 0.01 & 0.01 & 0.05 & 0.07 & 0.19 & 0.06 \\
\hline Nepal C.O. & 0.01 & 0.01 & $<0.01$ & 0.11 & 0.18 & 0.37 \\
\hline South Pole & 0.08 & 0.65 & 0.44 & 0.69 & 0.71 & 0.72 \\
\hline Mt. Washington & 0.25 & 0.38 & 0.01 & 0.02 & 0.02 & 0.29 \\
\hline \multicolumn{7}{|c|}{ Marine boundary layer } \\
\hline Neumayer & 0.02 & 0.74 & 0.57 & 0.62 & 0.71 & 0.68 \\
\hline Point Barrow & 0.04 & 0.03 & 0.06 & 0.02 & 0.07 & 0.04 \\
\hline Sable Island & 0.37 & 0.31 & $<0.01$ & 0.43 & 0.25 & 0.57 \\
\hline \multicolumn{7}{|c|}{ Continental boundary layer } \\
\hline Hyytiälä & 0.13 & 0.01 & 0.06 & 0.26 & 0.39 & 0.43 \\
\hline Pallas & 0.12 & 0.19 & 0.07 & 0.25 & 0.55 & 0.59 \\
\hline Melpitz & 0.06 & 0.02 & 0.05 & 0.07 & 0.28 & 0.41 \\
\hline Tomsk & 0.14 & 0.05 & 0.26 & $<0.01$ & 0.04 & $<0.01$ \\
\hline Listvyanka & 0.09 & 0.05 & 0.20 & $<0.01$ & 0.13 & 0.07 \\
\hline Harwell & 0.25 & 0.10 & 0.12 & 0.33 & 0.40 & 0.48 \\
\hline Weybourne & $<0.01$ & 0.08 & 0.03 & 0.02 & 0.05 & 0.03 \\
\hline India Himilaya & 0.18 & 0.40 & 0.25 & 0.61 & $<0.01$ & 0.01 \\
\hline Utö & 0.08 & 0.03 & 0.26 & 0.10 & 0.10 & 0.30 \\
\hline Värriö & 0.03 & $<0.01$ & $<0.01$ & 0.06 & 0.56 & 0.65 \\
\hline Tannus & 0.21 & 0.14 & 0.27 & 0.25 & 0.21 & 0.29 \\
\hline
\end{tabular}

the anthropogenic primary sulfate and carbonaceous aerosol size distributions. Reducing the emission size of primary carbonaceous (PRICAR) or sulfate (PRISUL) particles (and so increasing the number emission) within the range assumed by previous studies did little to improve the spatial pattern of simulated $\mathrm{CN}$ but reduced the model bias (PRICAR, NMB $=-12 \%$; PRISUL, NMB $=34 \%$ ) (these experiments included particle formation through binary homogeneous nucleation). However, scaling the anthropogenic primary emissions in this way did not improve the simulated seasonal cycle, with model performance degraded in the MBL (PRICAR, $R^{2}=0.21$; PRISUL, $R^{2}=0.36$ ) and FT (PRICAR, $R^{2}=0.12$; PRISUL, $R^{2}=0.22$ ) while only slightly improved in the continental BL (PRICAR, $R^{2}=0.14$; PRISUL, $R^{2}=0.18$ ).

We tested an empirical nucleation mechanism which assumes that the formation rate of 1-nm nuclei $\left(J_{1}\right)$ is proportional to the gas-phase sulfuric acid concentration to the power 1 (activation mechanism, $J_{1}=A\left[H_{2} S_{4}\right]$ ) or 2 (kinetic mechanism, $J_{1}=A\left[\mathrm{H}_{2} \mathrm{SO}_{4}\right]^{2}$ ). We limited the empirical mechanism to the BL and allowed binary homogeneous nucleation to occur above. When the model included a combination of these mechanisms along with primary emissions both the spatial pattern of annual mean $\mathrm{CN}$ and the sea-

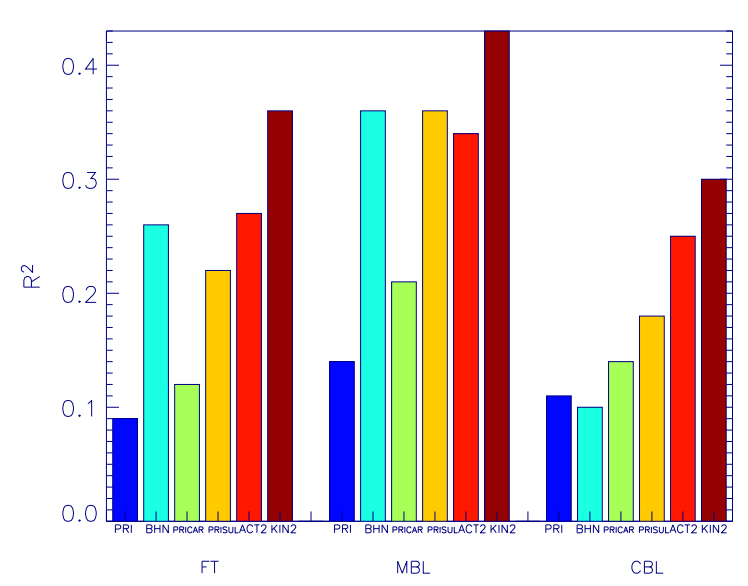

Fig. 7. Correlation coefficients $\left(R^{2}\right)$ between simulated and observed monthly mean $\mathrm{CN}$ concentrations calculated for the FT, MBL and continental BL (CBL) sites in Table 4. Model runs are described in Table 1.

sonal cycle of $\mathrm{CN}$ in the FT (activation, $R^{2}=0.27$; kinetic, $R^{2}=0.36$ ), MBL (activation, $R^{2}=0.34$; kinetic, $R^{2}=0.43$ ) and continental BL (activation, $R^{2}=0.25$; kinetic, $R^{2}=0.30$ ) was well captured. 


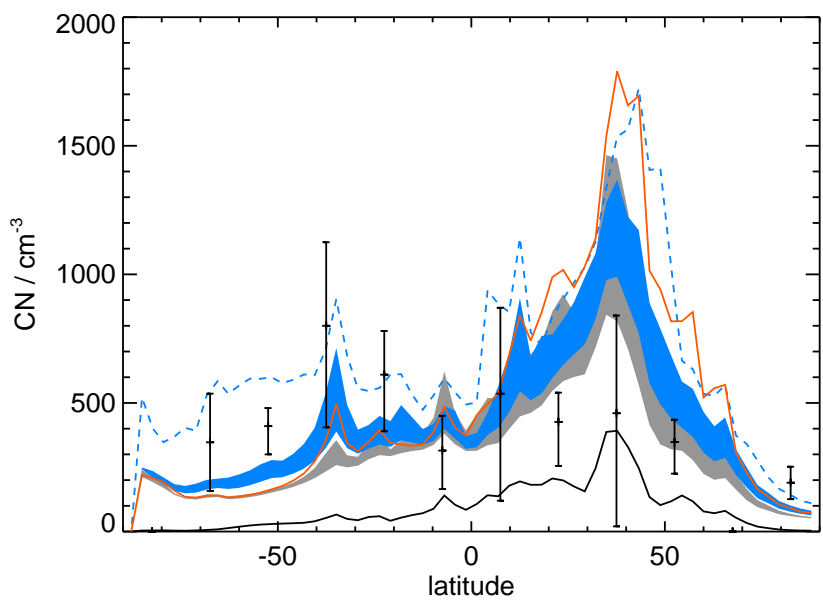

Fig. 8. Annual mean surface $\mathrm{CN}$ concentrations over the global oceans versus latitude. Observations (vertical bars) have been compiled from several field campaigns (Heintzenberg et al., 2000) and show mean concentrations \pm one standard deviation. The model experiments are described in Table 1: Black line shows the model with primary particulate emissions only (PRI), bottom of grey shading shows model with primary emissions and $\mathrm{BHN}$ (BHN), top of grey shading shows model with BHN and increased EC/OC number emission (PRICAR). Red line shows model with BHN and increased primary sulfate number emission (PRISUL). Blue shading shows model with primary emissions, BHN and activation BL particle formation, with the width of shading showing sensitivity to varying nucleation coefficients from $A=2 \times 10^{-7} \mathrm{~s}^{-1}$ (ACT1) to $A=2 \times 10^{-5} \mathrm{~s}^{-1}$ (ACT3). All model experiments are for $\mathrm{CN}$ $(>12 \mathrm{~nm})$ except the blue dashed line which shows $\mathrm{CN}(>3 \mathrm{~nm})$ for the ACT2 simulation.

The simulated nucleation rate depends on the nucleation rate coefficient, $A$, the magnitude of which is poorly known. We estimated a global-average value for this coefficient by running multiple experiments with different rates and finding the experiment that most reduced the model bias. The best agreement was with $A=2 \times 10^{-6} \mathrm{~s}^{-1}$ to $A=2 \times 10^{-5} \mathrm{~s}^{-1}$ for the activation scheme and with $A=2 \times 10^{-12} \mathrm{~cm}^{-3} \mathrm{~s}^{-1}$ for the kinetic scheme, which agree with the rates derived from observed particle formation events (Riipinen et al., 2007; Kuang et al., 2008).

The applicability of the BL particle formation mechanism over oceanic regions requires further analysis. All long-term MBL observations are at coastal locations where they may be influenced by continental aerosol sources. Observed $\mathrm{CN}$ concentrations at a remote tropical MBL site (Samoa) was well matched by the model with binary homogeneous nucleation. The mid-latitude MBL sites used in this analysis are more heavily influenced by continental emissions and therefore may not well represent remote MBL conditions unless a detailed screening of the observations is performed. At these sites, as in the continental BL, either BL particle formation or increased number emission from primary anthropogenic sources was needed to reduce the bias between model and observations. The model underpredicted $\mathrm{CN}$ at Mace Head even with the fastest BL nucleation rates used in this study. This may be due to alternate nucleation mechanisms driven by iodine compounds being important in this location (O'Dowd et al., 2002b; Vuollekoski et al., 2009).

In place of long-term open-ocean MBL observations we used a compilation of data from several field campaigns that has been gridded into $15^{\circ}$ oceanic latitude bands (Heintzenberg et al., 2000). Without any new particle formation (primary particulate emissions only) the model greatly underpredicts $\mathrm{CN}$ throughout the global oceans. As seen in previous studies, models that include primary emissions and binary homogeneous nucleation consistently underpredict $\mathrm{CN}$ concentrations in the Southern Ocean whilst either well predicting or overpredicting $\mathrm{CN}$ in the Northern Hemisphere. Over the Northern Hemisphere oceans, BL nucleation results in further overprediction of $\mathrm{CN}$, whereas over the Southern Ocean BL particle formation improves simulated $\mathrm{CN}$ concentrations. However, this model-observation discrepancy in the SH oceans has also been attributed to ultra-fine sea-spray (Pierce and Adams, 2006).

Our comparison between monthly mean model and observed total particle number concentrations has demonstrated that a binary homogeneous sulfuric acid-water nucleation mechanism improves simulated particle number in the FT whereas an empirical new particle formation mechanism based on sulfuric acid improves simulated particle number in the continental BL. Both the kinetic- and activation-type mechanisms equally matched the observations so our analysis was not able to determine which mechanism appears to be dominant in the atmosphere.

In future work we will attempt to gain further insight into the particle formation mechanism through a detailed analysis of particle formation events including evaluation of simulated particle formation and growth rates. Because the rate of new particle formation is sensitive both to the concentration of gaseous sulfuric acid and to the pre-existing aerosol surface area (Spracklen et al., 2006) there is a need to evaluate the model at a range of sites where observations of both are available. Models also need to be tested against recent observations that suggest an important role for atmospheric mixing in the BL (Wehner et al., 2010). A detailed analysis of particle concentrations in the free and upper troposphere is needed to better understand particle formation in this important region of the atmosphere. Recent laboratory experiments have suggested that in addition to sulfuric acid, organics may play a role in the nucleation process under atmospheric conditions (Metzger et al., 2010). Targeted field campaigns in a range of contrasting environments are now needed along with model studies to evaluate the contribution of this mechanism to particle formation in the real atmosphere.

Primary aerosol sources can suppress nucleation through providing a condensation sink for sulfuric acid vapor and scavenging newly formed particles through increasing the coagulation sink. Previous studies have shown that dust 
particles can reduce $\mathrm{CN}$ concentrations within dusty regions by up to $20 \%$ through this mechanism (Manktelow et al., 2010). Future studies must therefore study the contribution of dust, primary biological aerosol particles (Heald and Spracklen, 2009) and trace metal emissions (Birmili et al., 2006) to particle surface area and the corresponding suppression of new particle formation. In addition, the role of nitrate aerosol which has so far not been accounted for must be evaluated.

The production of $\mathrm{CCN}$ from particle formation also depends on particle growth rates which depend greatly on the availability of SOA precursors. A better understanding of particle growth rates is therefore important to understand the role of particle formation in the production of climate relevant particles. In Merikanto et al. (2009) we use the model evaluated here to quantify the contribution of both particle formation and primary particles to regional and global $\mathrm{CN}$ and $\mathrm{CCN}$ concentrations.

Acknowledgements. This work was supported through an NERC Advanced Fellowship, NERC APPRAISE, NERC AEROFORM NE/D01395X/1 and EUCAARI. We acknowledge the UK Air Quality Archive (http://www.airquality.co.uk/), EU CREATE (http://tarantula.nilu.no/projects/ccc/create/), EU EUSAAR (http://ebas.nilu.no), Global Atmospheric Watch World Data Centre for Aerosols (http://wdca.jrc.ec.europa.eu/), Atmospheric Investigation, Regional, Modeling, Analysis and Prediction (AIRMAP) program (www.airmap.unh.edu), British Atmospheric Data Centre (http://badc.nerc.ac.uk/home/), US Department of Energy, Atmospheric Radiation Measurements program (ARM) for provision of data.

Edited by: K. Lehtinen

\section{References}

Aalto, P., Hämeri, K., Becker, E., Weber, R., Salm, J., Mäkelä, J., Hoell, C., O’Dowd, C., Karlsson, H., Hansson, H.C., Väkevä, M., Koponen, I., Buzorius, G., and Kulmala, M.: Physical characterization of aerosol particles during nucleation events, Tellus B, 53, 344-358, 2001.

Adams, P. and Seinfeld, J.: Predicting global aerosol size distributions in general circulation models, J. Geophys. Res., 107(D19), 4370, doi:10.1029/2001JD001010, 2002.

Adams, P. and Seinfeld, J.: Disproportionate impact of particulate emissions on global cloud condensation nuclei concentrations, Geophys. Res. Lett., 30(5), 43-46, 2003.

Anttila, T., Vehkamäki, H., Napari, I., and Kulmala, M.: Effect of ammonium bisulfate formation on atmospheric water-sulphuric acid-ammonia nucleation, Boreal Environ. Res., 10, 511-523, 2005.

Arnold, S., Chipperfield, M., and Blitz, M.: A three-dimensional model study of the effect of new temperature-dependent quantum yields for acetone photolysis, J. Geophys. Res., 110, D22305, doi:10.1029/2005JD005998, 2005.

Benkovitz, C., Scholtz, M., Pacyna, J., Tarrasón, L., Dignon, J., Voldner, E., Spiro, P., Logan, J., and Graedel, T.: Global gridded inventories of anthropogenic emissions of sulfur and nitrogen, $\mathrm{J}$ Geophys. Res., 101(D22), 29239-29253, 1996.

Birmili, W. and Wiedensohler, A.: New particle formation in the continental boundary layer: Meteorological and gas phase parameter influence, Geophys. Res. Lett., 27(20), 3325-3328, 2000.

Birmili, W., Berresheim, H., Plass-Dlmer, C., Elste, T., Gilge, S., Wiedensohler, A., and Uhrner, U.: The Hohenpeissenberg aerosol formation experiment (HAFEX): a long-term study including size-resolved aerosol, $\mathrm{H}_{2} \mathrm{SO}_{4}, \mathrm{OH}$, and monoterpenes measurements, Atmos. Chem. Phys., 3, 361-376, doi:10.5194/acp-3-361-2003, 2003.

Birmili, W., Allen, A., Bary, F., and Harrison, R.: Trace metal concentrations and water solubility in size-fractionated atmospheric particles and influence of road traffic, Environ. Sci. Technol., 40(4), 1144-1153, 2006.

Birmili, W., Ries, L., Sohmer, R., Anastou, A., Sonntag, A., König, K., and Levin, I.: Fine and ultrafine aerosol particles at the GAW station Schneefernerhaus/Zugspitze, Gefahrstoffe Reinhaltung Luft, 69(1/2), 31-35, 2009.

Bodhaine, B.: Aerosol measurements at four background sites, J. Geophys. Res., 88, 10753-10768, 1983.

Bonn, B., Kulmala, M., Riipinen, I., Sihto, S.-L., and Ruuskanen, T.: How biogenic terpenes govern the correlation between sulfuric acid concentrations and new particle formation, J. Geophys. Res., 113, D12209, doi:10.1029/2007JD009327, 2008.

Boy, M., Kazil, J., Lovejoy, E., Guenther, A., and Kulmala, M.: Relevance of ion-induced nucleation of sulfuric acid and water in the lower troposphere over the boreal forest at northern latitudes, Atmos. Res., 90, 151-158, 2008.

Chang, L.-S., Schwartz, S., McGraw, R., and Lewis, E.: Sensitivity of aerosol properties to new particle formation mechanism and to primary emissions in a continental-scale chemical transport model, J. Geophys. Res., 114, D07203, doi:10.1029/2008JD011019, 2009.

Charron, A., Birmili, W., and Harrison, R.: Factors influencing new particle formation at the rural site, Harwell, UK, J. Geophys. Res., 112, D14210, doi:10.1029/2007JD008425, 2007.

Chipperfield, M.: New version of the TOMCAT/SLIMCAT offline chemical transport model: intercomparison of stratospheric tracer experiments, Q. J. Roy. Meteorol. Soc., 132, 1179-1203, doi:10.1256/qj.05.51, 2006.

Clarke, A. and Kapustin, V.: A pacific aerosol survey. Part I: A decade of data on particle production, transport, evolution, and mixing in the troposphere, J. Atmos. Sci., 59(3), 363-382, 2002.

Clarke, A., Davis, D., Kapustin, V., Eisele, F., Chen, G., Paluch, I., Lenschow, D., Bandy, A., Thornton, D., Moore, K., Mauldin, L., Tanner, D., Litchy, M., Carroll, M., Collins, J., and Albercook, G.: Particle nucleation in the tropical boundary layer and its coupling to marine sulfur sources, Science, 282, 89-92, 1998.

Clarke, A., Eisele, F., Kapustin, V., Moore, K., Tanner, D., Mauldin, L., Litchy, M., Lienert, B., Carroll, M., and Albercook, G.: Nucleation in the equatorial free troposphere: Favorable environments during PEM-Tropics, J. Geophys. Res., 104(D5), 5735-5744, 1999.

Dal Maso, M., Kulmala, M., Riipinen, I., Wagner, R., Hussein, T., Aalto, P., and Lehtinen, K.: Formation and growth of fresh atmospheric aerosols: eight years of aerosol size distribution data from SMEAR II, Hyytiälä, Finland, Boreal Environ. Res., 10, 
323-336, 2005.

Dal Maso, M., Hyvärinen, A., Komppula, M., Tunved, P., Kerminen, V.-M., Lihavainen, H., Viisanen, Y., Hansson, H.-C., and Kulmala, M.: Annual and interannual variation in boreal forest aerosol particle number and volume concentration and their connection to particle formation, Tellus, 60B, 495-508, 2008a.

Dal Maso, M., Sogacheva, L., Anisimov, M., Arshinov, M., Baklanov, A., Belan, B., Khodzher, T., Obolkin, V., Staroverova, A., Vlasov, A., Zagaynov, V., Lushnikov, A., Lyubovtseva, Y., Riipinen, I., Kerminen, V.-M., and Kulmala, M.: Aerosol particle formation events at two Siberian stations inside the boreal forest, Boreal Environ. Res., 13, 81-92, 2008 b.

Delene, D. and Ogren, J.: Variability of aerosol optical properties at four North American surface monitoring sites, J. Atmos. Sci., 59, 1135-1150, 2002.

Dentener, F., Kinne, S., Bond, T., Boucher, O., Cofala, J., Generoso, S., Ginoux, P., Gong, S., Hoelzemann, J. J., Ito, A., Marelli, L., Penner, J. E., Putaud, J.-P., Textor, C., Schulz, M., van der Werf, G. R., and Wilson, J.: Emissions of primary aerosol and precursor gases in the years 2000 and 1750 prescribed data-sets for AeroCom, Atmos. Chem. Phys., 6, 4321-4344, doi:10.5194/acp6-4321-2006, 2006.

Easter, R., Ghan, S., Zhang, Y., Saylor, R., Chapman, E., Laulainen, N., Abdul-Razzak, H., Leung, L., Bian, X., and Zaveri, R.: MIRAGE: Model description and evaluation of aerosols and trace gases, J. Geophys. Res., 109, D20210, doi:10.1029/2004JD004571, 2004.

Elleman, R. A. and Covert, D.: Aerosol size distribution modeling with the community multiscale air quality modeling system in the Pacific Northwest: 2. parameterizations for ternary nucleation and nucleation mode processes, J. Geophys. Res., 114, D11207, doi:10.1029/2009JD012187, 2009.

Engler, C., Rose, D., Wehner, B., Wiedensohler, A., Brggemann, E., Gnauk, T., Spindler, G., Tuch, T., and Birmili, W.: Size distributions of non-volatile particle residuals $(D p<800 \mathrm{~nm})$ at a rural site in Germany and relation to air mass origin, Atmos. Chem. Phys., 7, 5785-5802, doi:10.5194/acp-7-5785-2007, 2007.

Gaydos, T. M., Stanier, C., and Pandis, S.: Modeling of in situ ultrafine atmospheric particle formation in the eastern United States, J. Geophys. Res., 110, D07S12, doi:10.1029/2004JD004683, 2005.

Gong, S., Barrie, L., Blanchet, J.-P., von Salzen, K., Lohmann, U., Lesins, G., Spacek, L., Zhang, L., Girard, E., Lin, H., Leaitch, R., Leighton, H., Chylek, P., and Huang, P.: Canadian aerosol module: A size-segregated simulation of atmospheric aerosol processes for climate and air quality models 1 . Module development, J. Geophys. Res., 108, 4007, doi:10.1029/2001JD002002, 2003.

Gras, J.: CN, CCN and particle size in Southern Ocean air at Cape Grim, Atmos. Res., 35, 233-251, 1995.

Guenther, A., Hewitt, C., Erickson, D., Geron, C., Graedal, T., Harley, P., Klinger, L., Lerdau, M., McKay, W., Pierce, T., Scholes, B., Steinbrecher, R., Tallamraju, R., Taylor, J., and Zimmerman, P.: A global model of natural volatile organic compound emissions, J. Geophys. Res., 100(D5), 8873-8892, 1995.

Hamed, A., Joutsensaari, J., Mikkonen, S., Sogacheva, L., Dal Maso, M., Kulmala, M., Cavalli, F., Fuzzi, S., Facchini, M. C., Decesari, S., Mircea, M., Lehtinen, K. E. J., and Laaksonen, A.: Nucleation and growth of new particles in Po Valley, Italy,
Atmos. Chem. Phys., 7, 355-376, doi:10.5194/acp-7-355-2007, 2007.

Heald, C. and Spracklen, D.: Atmospheric budget of primary biological aerosol particles from fungal spores, Geophys. Res. Lett., 36, L09806, doi:10.1029/2009GL037493, 2009.

Heintzenberg, J., Covert, D., and Van Dingenen, R.: Size distribution and chemical composition of marine aerosols: a compilation and review, Tellus B, 52, 1104-1122, 2000.

Heintzenberg, J., Birmili, W., Theiss, D., and Kisilyakhov, Y.: The atmospheric aerosol over Siberia, as seen from the $300 \mathrm{~m}$ ZOTTO tower, Tellus, 60B, 276-285, doi:10.1111/j.1600 0889.2007.00335.x, 2008.

Jaecker-Voirol, A. and Mirabel, P.: Nucleation rate in a binary mixture of sulfuric acid and water vapour, J. Phys. Chem., 92, 35183521, 1988.

Kazil, J., Lovejoy, E. R., Barth, M. C., and O'Brien, K.: Aerosol nucleation over oceans and the role of galactic cosmic rays, Atmos. Chem. Phys., 6, 4905-4924, doi:10.5194/acp-6-4905-2006, 2006.

Kerminen, V.-M. and Kulmala, M.: Analytical formulae connecting the "real" and the apparent nucleation rate and the nuclei number concentration for atmospheric nucleation events, J. Aerosol Sci., 33, 609-622, 2002.

Kettle, A. and Andreae, M.: Flux of dimethylsulfide from the oceans: A comparison of updated data sets and flux models, J. Geophys. Res., 105, 26793-26808, 2000.

Kivekäs, N., Sun, J., Zhan, M., Kerminen, V.-M., Hyvärinen, A., Komppula, M., Viisanen, Y., Hong, N., Zhang, Y., Kulmala, M., Zhang, X.-C., Deli-Geer, and Lihavainen, H.: Long term particle size distribution measurements at Mount Waliguan, a highaltitude site in inland China, Atmos. Chem. Phys., 9, 5461-5474, doi:10.5194/acp-9-5461-2009, 2009.

Komppula, M., Lihavainen, H., Hatakka, J., Paatero, J., Aalto, P., Kulmala, M., and Viisanen, Y.: Observations of new particle formation and size distributions at two different heights and surroundings in subarctic area in northern Finland, J. Geophys. Res., 108(D9), 4295, doi:10.1029/2002JD002939, 2003.

Komppula, M., Sihto, S.-L., Korhonen, H., Lihavainen, H., Kerminen, V.-M., Kulmala, M., and Viisanen, Y.: New particle formation in air mass transported between two measurement sites in Northern Finland, Atmos. Chem. Phys., 6, 2811-2824, doi:10.5194/acp-6-2811-2006, 2006.

Komppula, M., Lihavainen, H., Hyvärinen, A.-P., Kerminen, V.-M., Panwar, T., Sharma, V., and Viisanen, Y.: Physical properties of aerosol particles at a Himalayan background site in India, J. Geophys. Res., 114, D12202, doi:10.1029/2008JD011007, 2009.

Koponen, I. K., Virkkula, A., Hillamo, R., Kerminen, V.M., and Kulmala, M.: Number size distributions and concentrations of the continental summer aerosols in Queen Maud Land, Antarctica, J. Geophys. Res., 108(D18), 4587, doi:10.1029/2003JD003614, 2003.

Korhonen, H., Carslaw, K., Spracklen, D., Ridley, D., and Ström, J.: A global model study of processes controlling aerosol size distributions in the Arctic spring and summer, J. Geophys. Res., 113, D08211, doi:10.1029/2007JD009114, 2008.

Kuang, C., McMurry, P., McCormick, A., and Eisele, F.: Dependence of nucleation rates on sulfuric acid vapor concentrations in diverse atmospheric locations, J. Geophys. Res., 113, D10209, doi:10.1029/2007JD009253, 2008. 
Kuang, C., McMurry, P., and McCormick, A.: Determination of cloud condensation nuclei production from measured new particle formation events, Geophys. Res. Lett., 36, L09822, doi:10.1029/2007JD009253, 2009.

Kulmala, M., Laaksonen, A., and Pirjola, L.: Parameterizations for sulfuric acid/water nucleation rates, J. Geophys. Res., 103(D7), 8301-8307, 1998a.

Kulmala, M., Toivonen, A., Mäkelä, J., and Laaksonen, A.: Analysis of the growth of nucleation mode particles observed in boreal forest, Tellus B, 50B, 449-462, 1998b.

Kulmala, M., Dal MAso, M., Mäkelä, J., Pirjola, L., Väkevä, M., Aalto, P., Miikkulainen, P., Hämeri, K., and O'Dowd, C.: On the formation, growth and composition of nucleation mode particles, Tellus B, 53B, 479-490, 2001.

Kulmala, M., Vehkamäki, H., Petajda, T., Dal Maso, M., Lauri, A., Kerminen, V., Birmili, W., and McMurry, P.: Formation and growth rates of ultrafine atmospheric particles: a review of observations, J. Aerosol Sci., 35, 143-176, 2004.

Kulmala, M., Lehtinen, K. E. J., and Laaksonen, A.: Cluster activation theory as an explanation of the linear dependence between formation rate of $3 \mathrm{~nm}$ particles and sulphuric acid concentration, Atmos. Chem. Phys., 6, 787-793, doi:10.5194/acp-6-787-2006, 2006.

Kulmala, M., Riipinen, I., Sipilä, M., Manninen, H., Petäjä, Junninen, H., Dal Maso, M., Mordas, G., Mirme, A., Vana, M., Hirsikko, A., Laakso, L., Harrison, R., Hanson, I., Leung, C., Lehtinen, K., and Kerminen, V.-M.: Toward direct measurement of atmospheric nucleation, Science, 318, 89-92, 2007.

Laakso, L., Laakso, H., Aalto, P. P., Keronen, P., Petäjä, T., Nieminen, T., Pohja, T., Siivola, E., Kulmala, M., Kgabi, N., Molefe, M., Mabaso, D., Phalatse, D., Pienaar, K., and Kerminen, V.-M.: Basic characteristics of atmospheric particles, trace gases and meteorology in a relatively clean Southern African Savannah environment, Atmos. Chem. Phys., 8, 4823-4839, doi:10.5194/acp-8-4823-2008, 2008.

Laaksonen, A., Hamed, A., Joutsensaari, J., Hiltunen, L., Cavalli, F., Junkermann, W., Asmi, A., Fuzzi, S., and Facchini, M. C.: Cloud condensation nucleus production from nucleation events at a highly polluted region, Geophys. Res. Lett., 32, L06812, doi:10.1029/2004GL022092, 2005.

Lucas, D. and Akimoto, H.: Evaluating aerosol nucleation parameterizations in a global atmospheric model, Geophys. Res. Lett., 33, L10808, doi:10.1029/2006GL025672, 2006.

Mäkelä, J., Aalto, P., Jokinen, V., Pohja, T., Nissinen, A., Palmroth, S., Markkanen, T., Seitsonen, K., Lihavainen, J., and Kulmala, M.: Observations of ultrafine particle formation and growth in boreal forest, Geophys. Res. Lett., 24(10), 1219-1222, 1997.

Makkonen, R., Asmi, A., Korhonen, H., Kokkola, H., Järvenoja, S., Räisänen, P., Lehtinen, K. E. J., Laaksonen, A., Kerminen, V.M., Järvinen, H., Lohmann, U., Bennartz, R., Feichter, J., and Kulmala, M.: Sensitivity of aerosol concentrations and cloud properties to nucleation and secondary organic distribution in ECHAM5-HAM global circulation model, Atmos. Chem. Phys., 9, 1747-1766, doi:10.5194/acp-9-1747-2009, 2009.

Manktelow, P., Mann, G., Carslaw, K., Spracklen, D., and Chipperfield, M.: Regional and global trends in sulfate since the 1980s, Geophys. Res. Lett., 34, L15803, doi:10.1029/2006GL028668, 2007.
Manktelow, P. T., Carslaw, K. S., Mann, G. W., and Spracklen, D. V.: The impact of dust on sulfate aerosol, $\mathrm{CN}$ and $\mathrm{CCN}$ during an East Asian dust storm, Atmos. Chem. Phys., 10, 365-382, doi:10.5194/acp-10-365-2010, 2010.

Mårtensson, E., Nilsson, E., de Leeuw, G., Cohen, L., and Hansson, H.: Laboratory simulations and parameterization of the primary marine aerosol production, J. Geophys. Res., 108(D9), 4297, doi:10.1029/2002JD002263, 2003.

McComiskey, A. E., Andrews, E., Jackson, D., Jefferson, A., Kim, S., Ogren, J., Sheridan, P., and Wendell, J.: Aerosols and Radiation, CMDL Summary report,, Tech. Rep. 27, CMDL, 2003.

McMurry, P. and Friedlander, S.: New particle formation in the presence of an aerosol, Atmos. Environ., 13, 1635-1651, 1979.

Merikanto, J., Napari, I., Vehkamäki, H., Antilla, T., and Kulmala, M.: New parameterization of sulfuric acid-ammonia-water ternary nucleation rates at topospheric conditions, J. Geophys. Res., 11, D15207, doi:10.1029/2006JD007977, 2007.

Merikanto, J., Spracklen, D. V., Mann, G. W., Pickering, S. J., and Carslaw, K. S.: Impact of nucleation on global CCN, Atmos. Chem. Phys., 9, 8601-8616, doi:10.5194/acp-9-8601-2009, 2009.

Metzger, A., Verheggen, B., Dommen, J., Duplissy, J., Prevot, A., Weingartner, E., Riipinen, I., Kulmala, M., Spracklen, D., Carslaw, K., and Baltensperger, U.: Atmospheric Chemistry Special Feature: Evidence for the role of organics in aerosol particle formation under atmospheric conditions, PNAS 2010107 (15) 6646-6651; published ahead of print January 19, 2010, doi:10.1073/pnas.0911330107.

Minikin, A., Petzold, A., Ström, J., Krejci, R., Seifert, M., van Velthoven, P., Schlager, H., Schumann, U.: Aircraft observations of the upper tropospheric fine particle aerosol in the Northen and Southern Hemispheres at midlatitudes, Geophys. Res. Lett., 30, 1503, doi:10.1029/2002GL016458, 2003.

Mirme, S., Mirme, A., Minikin, A., Petzold, A., Hrrak, U., Kerminen, V.-M., and Kulmala, M.: Atmospheric sub-3 nm particles at high altitudes, Atmos. Chem. Phys., 10, 437-451, doi:10.5194/acp-10-437-2010, 2010.

Modgil, M., Kumar, S., Tripathi, S., and Lovejoy, E.: A parameterization of ion-induced nucleation of sulfuric acid and water for atmospheric conditions, J. Geophys. Res., 110, D19205, doi:10.1029/2004JD005475, 2005.

Napari, I., Noppel, M., Vehkamäki, H., and Kulmala, M.: An improved model for ternary nucleation of sulfuric acid-ammoniawater, J. Chem. Phys., 116, 4221-4227, 2002.

Nightingale, P., Liss, P., and Schlosser, P.: Measurements of air-sea gas transfer during an open ocean algal bloom, Geophys. Res. Lett., 27(14), 2117-2120, 2000.

O'Dowd, C., Geever, M., Hill, M., Smith, M., and Jennings, S.: New particle formation: Nucleation rates and spatial scales in the clean marine coastal environment, Geophys. Res. Lett., 25(10), 1661-1664, 1998.

O'Dowd, C., Lowe, J., Smith, M., and Kaye, A.: The relative importance of non-sea-salt sulphate and sea-salt aerosol to the marine cloud condensation nuclei population: An improved multicomponent aerosol-cloud droplet parametrization, Q. J. Roy. Meteorol. Soc., 125, 1295-1313, 1999.

O’Dowd, C., Jimenez, J., Bahreini, R., Flagan, R., Seinfeld, J., Hämeri, K., Pirjola, L., Kulmala, M., Jennings, S., and Hoff- 
mann, T.: Marine aerosol formation from biogenic iodine emissions, Nature, 417, 632-636, 2002.

O’Dowd, C. D., Hämeri, K., Mäkelä, J. M., Pirjola, L., Kulmala, M., Jennings, S. G., Berresheim, H., Hansson, H.-C., de Leeuw, G., Allen, A. G., Hewitt, C. N., Jackson, A., Viisanen, Y., Hoffmann, T.: A dedicated study of new particle formation and fate in the coastal environment (PARFORCE): Overview of objectives and initial achievements, J. Geophys. Res., 107(D19), 8108, doi:10.1029/2001000555, 2002.

O’Dowd, C. D., Yoon, Y. J., Junkermann, W., Aalto, P., Kulmala, M., Lihavainen, H., and Viisanen, Y.: Airborne measurements of nucleation mode particles II: boreal forest nucleation events, Atmos. Chem. Phys., 9, 937-944, doi:10.5194/acp-9-937-2009, 2009.

Pierce, J. and Adams, P.: Global evaluation of CCN formation by direct emission of sea salt and growth of ultrafine sea salt, J. Geophys. Res., 111, D06203, doi:10.1029/2005JD006186, 2006.

Pierce, J., Theodoritsi, G., Adams, P., and Pandis, S. N.: Parameterization of the effect of sub-grid scale aerosol dynamics on aerosol number emission rates, J. Aerosol Sci., 40(5), 385-393, 2009.

Pierce, J. R. and Adams, P. J.: Uncertainty in global CCN concentrations from uncertain aerosol nucleation and primary emission rates, Atmos. Chem. Phys., 9, 1339-1356, doi:10.5194/acp-91339-2009, 2009.

Pierce, J. R., Chen, K., and Adams, P. J.: Contribution of primary carbonaceous aerosol to cloud condensation nuclei: processes and uncertainties evaluated with a global aerosol microphysics model, Atmos. Chem. Phys., 7, 5447-5466, doi:10.5194/acp-75447-2007, 2007.

Raes, F., Van Dingenen, R., Vignati, E., Wilson, J., Putaud, J.-P., Seinfeld, J., and Adams, P.: Formation and cycling of aerosols in the global troposphere, Atmos. Environ., 34, 4215-4240, 2000.

Reade, L., Jennings, S., and McSweeney, G.: Cloud condensation nuclei measurements at Mace Head, Ireland, over the period 1994-2002, Atmos. Environ., 82, 610-621, 2006.

Riipinen, I., Sihto, S.-L., Kulmala, M., Arnold, F., Dal Maso, M., Birmili, W., Saarnio, K., Teinilä, K., Kerminen, V.-M., Laaksonen, A., and Lehtinen, K. E. J.: Connections between atmospheric sulphuric acid and new particle formation during QUEST III-IV campaigns in Heidelberg and Hyytiälä, Atmos. Chem. Phys., 7, 1899-1914, doi:10.5194/acp-7-1899-2007, 2007.

Schröder, F., Kärcher, B., Fiebig, M., and Petzold, A.: Aerosol states in the free troposphere at northern midlatitudes, J. Geophys. Res., 107(D21), 8126-8133, 2002.

Sihto, S.-L., Kulmala, M., Kerminen, V.-M., Dal Maso, M., Petäjä, T., Riipinen, I., Korhonen, H., Arnold, F., Janson, R., Boy, M., Laaksonen, A., and Lehtinen, K. E. J.: Atmospheric sulphuric acid and aerosol formation: implications from atmospheric measurements for nucleation and early growth mechanisms, Atmos. Chem. Phys., 6, 4079-4091, doi:10.5194/acp-6-4079-2006, 2006.

Singh, H., Anderson, B., Avery, M., Viezee, W., Chen, Y., Tabazadeh, A., Hamill, P., Pueschel, R., Fuelberg, H., and Hannan, J.: Global distribution and sources of volatile and nonvolatile aerosol in the remote troposphere, J. Geophys. Res., 107(D11), 4121, doi:10.1029/2001JD000486, 2002.

Spracklen, D., Carslaw, K., Kulmala, M., Kerminen, V.-M., Sihto, S.-L., Riipinen, I., Merikanto, J., Mann, G., Chipper- field, M., Wiedensohler, A., Birmili, W., and Lihavainen, H.: Contribution of particle formation to global cloud condensation nuclei concentrations, Geophys. Res. Lett., 35, L06808, doi:10.1029/2007GL033038, 2008.

Spracklen, D. V., Pringle, K. J., Carslaw, K. S., Chipperfield, M. P., and Mann, G. W.: A global off-line model of sizeresolved aerosol microphysics: I. Model development and prediction of aerosol properties, Atmos. Chem. Phys., 5, 22272252, doi:10.5194/acp-5-2227-2005, 2005.

Spracklen, D. V., Pringle, K. J., Carslaw, K. S., Chipperfield, M. P., and Mann, G. W.: A global off-line model of size-resolved aerosol microphysics: II. Identification of key uncertainties, Atmos. Chem. Phys., 5, 3233-3250, doi:10.5194/acp-5-3233-2005, 2005.

Spracklen, D. V., Carslaw, K. S., Kulmala, M., Kerminen, V.-M., Mann, G. W., and Sihto, S.-L.: The contribution of boundary layer nucleation events to total particle concentrations on regional and global scales, Atmos. Chem. Phys., 6, 5631-5648, doi:10.5194/acp-6-5631-2006, 2006.

Spracklen, D. V., Pringle, K. J., Carslaw, K. S., Mann, G. W., Manktelow, P., and Heintzenberg, J.: Evaluation of a global aerosol microphysics model against size-resolved particle statistics in the marine atmosphere, Atmos. Chem. Phys., 7, 20732090, doi:10.5194/acp-7-2073-2007, 2007.

Stier, P., Feichter, J., Kinne, S., Kloster, S., Vignati, E., Wilson, J., Ganzeveld, L., Tegen, I., Werner, M., Balkanski, Y., Schulz, M., Boucher, O., Minikin, A., and Petzold, A.: The aerosolclimate model ECHAM5-HAM, Atmos. Chem. Phys., 5, 11251156, doi:10.5194/acp-5-1125-2005, 2005.

Trivitayanurak, W., Adams, P. J., Spracklen, D. V., and Carslaw, K. S.: Tropospheric aerosol microphysics simulation with assimilated meteorology: model description and intermodel comparison, Atmos. Chem. Phys., 8, 3149-3168, doi:10.5194/acp-83149-2008, 2008.

Vana, M., Kulmala, M., Maso, D., Hörrak, M., and Tamm, E.: Comparative study of nucleation mode aerosol particles and intermediate air ions formation events at three sites, J. Geophys. Res., 109(D17), D17201, doi:10.1029/2003JD004413, 2004.

Vehkamäki, H., Kulmala, M., Napari, I., Lehtinen, K., Timmreck, C., Noppel, M., and Laaksonen, A.: An improved parametrization for sulfuric acid-water nucleation rates for tropospheric and stratospheric conditions, J. Geophys. Res., 107(22), 4622-4631, 2002.

Vehkamäki, H., Napari, I., Kulmala, M., and Noppel, M.: Stable ammonium bisulfate clusters in the atmosphere, Phys. Rev. Lett. 93(14), 148501, doi:10.1103/PhysRevLett.93.14850, 2004.

Venzac, H., Sellegri, K., Laj, P., Villani, P., Bonasoni, P., Marinoni, A., Cristofanelli, P., Calzolari, F., Fuzzi, S., Decesari, S., Facchini, M.-C., Vuillermoz, E., and Verza, G. P.: High frequency new particle formation in the Himilayas, P. Natl. Acad. Sci. USA, 105, 15666-15671, 2008.

Venzac, H., Sellegri, K., Villani, P., Picard, D., and Laj, P.: Seasonal variation of aerosol size distributions in the free troposphere and residual layer at the puy de Dme station, France, Atmos. Chem. Phys., 9, 1465-1478, doi:10.5194/acp-9-1465-2009, 2009.

Verheggen, B., Mozurkewich, M., Caffrey, P., Hoppel, W., and Sullivan, W.: Alpha-pinene oxidation in the presence of seed aerosol: Estimates of nucleation rates, growth rates, and yield, Environ. Sci. Technol., 41(17), 6046-6051, 2007. 
Vuollekoski, H., Kerminen, V.-M., Anttila, T., Sihto, S.L., Vana, M., Ehn, M., Korhonen, H., McFiggans, G., O'Dowd, C. D., and Kulmala, M.: Iodine dioxide nucleation simulations in coastal and remote marine environments, J. Geophys. Res., 114, D02206, doi:10.1029/2008JD010713, 2009.

Wang, M. and Penner, J. E.: Aerosol indirect forcing in a global model with particle nucleation, Atmos. Chem. Phys., 9, 239-260, doi:10.5194/acp-9-239-2009, 2009.

Wang, M., Penner, J., and Liu, X.: The coupled IMPACT aerosol and NCAR CAM3 model: Evaluation of predicted aerosol number and size distribution, J. Geophys. Res., 114, D06302, doi:10.1029/2008JD010459, 2009.

Weber, R., Marti, J., McMurry, P., Eisele, F., Tanner, D., and Jefferson, A.: Measured atmospheric new particle formation rates: Implications for nucleation mechanisms, Chem. Eng. Commun., 151, 53-64, 1996.

Weber, R., McMurry, P., Mauldin III, R., Tanner, D., Eisele, F., Clarke, A., and Kapustin, V.: New particle formation in the remote troposphere: A comparison of observations at various sites, Geophys. Res. Lett., 26(3), 307-310, 1999.

Wehner, B., Siebert, H., Ansmann, A., Ditas, F., Seifert, P., Stratmann, F., Wiedensohler, A., Apituley, A., Shaw, R. A., Manninen, H. E., and Kulmala, M.: Observations of turbulence-induced new particle formation in the residual layer, Atmos. Chem. Phys., 10, 4319-4330, doi:10.5194/acp-10-4319-2010, 2010.
Wiedensohler, A., Cheng,i Y. F., Nowak, A., Wehner, B., Achtert, P., Berghof, M., Birmili, W., Rose, D., Pöschl, U., Hu, M., Zhu, T., Takegawa, N., Kita, K., Kondo, Y., and Lou, S. R.: Rapid particle growth by secondary aerosol formation to $\mathrm{CCN}$ - A case study for the polluted aerosol in North-Eastern China, J. Geophys. Res. 114, D00G08, doi:10.1029/2008JD010884,2009.

Weingartner, E., Nyeki, S., and Baltensperger, U.: Seasonal and diurnal variation of aerosol size distributions $(10<D<750 \mathrm{~nm})$ at a high-alpine site (Jungfraujoch $3580 \mathrm{~m}$ a.s.1.), J. Geophys. Res., 104(D21), 26809-26820, 1999.

Weller, R. and Lampert, A.: Optical properties and sulfate scattering efficiency of boundary layer aerosol at coastal Neumayer Station, J. Geophys. Res., 113, D16208, doi:10.1029/2008JD009962, 2008.

Yu, F.: Effect of ammonia on new particle formation: a kinetic $\mathrm{H}_{2} \mathrm{SO}_{4}-\mathrm{H}_{2} \mathrm{O}-\mathrm{NH}_{3}$ nucleation model constrained by laboratory measurements, J. Geophys. Res., 111, D01204, doi:10.1029/2005JD005968, 2006.

Yu, F., Wang, Z., Luo, G., and Turco, R.: Ion-mediated nucleation as an important global source of tropospheric aerosols, Atmos. Chem. Phys., 8, 2537-2554, doi:10.5194/acp-8-2537-2008, 2008.

Ziemba, L., Griffin, R., and Talbot, R.: Observations of elevated particle number concentration events at a rural site in New England, J. Geophys. Res., 111, D23S34, doi:10.1029/2006JD007607, 2007. 